FEDERAL RESERVE BANK OF SAN FRANCISCO

WORKING PAPER SERIES

\title{
Cross-Country Causes and Consequences of the 2008 Crisis: Early Warning
}

\author{
Andrew K. Rose \\ Haas School of Business, U.C. Berkeley \\ Mark M. Spiegel \\ Federal Reserve Bank of San Francisco
}

July 2009

Working Paper 2009-17

http://www.frbsf.org/publications/economics/papers/2009/wp09-17bk.pdf

The views in this paper are solely the responsibility of the authors and should not be interpreted as reflecting the views of the Federal Reserve Bank of San Francisco or the Board of Governors of the Federal Reserve System. This paper was produced under the auspices of the Center for Pacific Basin Studies within the Economic Research Department of the Federal Reserve Bank of San Francisco. 


\title{
Cross-Country Causes and Consequences of the 2008 Crisis: Early Warning \\ Andrew K. Rose and Mark M. Spiegel*
}

Comments Welcome

Revised as of: July 1, 2009

\begin{abstract}
This paper models the causes of the 2008 financial crisis together with its manifestations, using a Multiple Indicator Multiple Cause (MIMIC) model. Our analysis is conducted on a cross-section of 107 countries; we focus on national causes and consequences of the crisis, ignoring crosscountry "contagion" effects. Our model of the incidence of the crisis combines 2008 changes in real GDP, the stock market, country credit ratings, and the exchange rate. We explore the linkages between these manifestations of the crisis and a number of its possible causes from 2006 and earlier. We include over sixty potential causes of the crisis, covering such categories as: financial system policies and conditions; asset price appreciation in real estate and equity markets; international imbalances and foreign reserve adequacy; macroeconomic policies; and institutional and geographic features. Despite the fact that we use a wide number of possible causes in a flexible statistical framework, we are unable to link most of the commonly-cited causes of the crisis to its incidence across countries. This negative finding in the cross-section makes us skeptical of the accuracy of "early warning" systems of potential crises, which must also predict their timing.
\end{abstract}

Keywords: empirical, data, cross-section, credit; stock; country; model; international; MIMIC.

JEL Classification Numbers: E65, F30

Andrew K. Rose

Haas School of Business

University of California

Berkeley, CA USA 94720-1900

Tel: (510) 642-6609

Fax: (510) 642-4700

E-mail: arose@haas.berkeley.edu
Mark M. Spiegel

FRB San Francisco

101 Market St.

San Francisco CA 94105

Tel: (415) 974-3241

Fax: (415) 974-2168

E-mail: mark.spiegel@sf.frb.org

* Rose is B.T. Rocca Jr. Professor of International Trade and Economic Analysis and Policy in the Haas School of Business at the University of California, Berkeley, NBER Research Associate and CEPR Research Fellow. Spiegel is Vice President, Economic Research, Federal Reserve Bank of San Francisco. We thank Haibin Zhu for sharing his real estate data. Helpful comments were received from: Joshua Aizenman, David Cook, Mike Dooley, Marcel Fratzscher, Sophia Rabe-Hesketh, Kadee Russ, and seminar participants at the BIS and the APEA. Rose thanks the Federal Reserve Bank of San Francisco for hospitality during the course of this research. Christopher Candelaria provided excellent research assistance. The views expressed below do not represent those of the Federal Reserve Bank of San Francisco or the Board of Governors of the Federal Reserve System. A current version of this paper, key output, and the main STATA data set used in the paper are available at http://faculty.haas.berkeley.edu/arose. 
"we agree ... that the FSB [Financial Stability Board] should collaborate with the IMF to provide early warning of macroeconomic and financial risks and the actions needed to address them"

- Final Communiqué G-20 Summit April 2, 2009

"Any early warning system to detect impending dangers to the world economy must find a way of bringing together the scatter of international and national macrofinancial expertise. We at the

Fund have already begun intensifying our early warning capabilities and will be strengthening our collaboration with others involved in this area."

- Dominique Strauss-Kahn ${ }^{2}$

\section{I: Motivation}

The 2008 global financial crisis is notable for a number of reasons, including most obviously its severity and speed. The international span of the crisis has also been remarkable; essentially all the industrialized countries have been affected, as well as a large number of developing and emerging economies. In this paper we seek to deepen our understanding of the international breadth of the crisis; we are particularly interested in modeling the causes of the crisis, and why its severity differs across countries.

We are interested in understanding the causes of 2008 the crisis both out of intrinsic interest, and to investigate the feasibility of modeling financial crises like this empirically. Economists do not have a particularly good track record at predicting the timing of crises, which is one of the objectives of an early warning system. ${ }^{3}$ Historically however, the profession has had some success at modeling the incidence of crises across firms, banks, and/or countries. ${ }^{4}$ That is, we find cross-sectional analysis easier than time-series analysis. In this paper, we attempt to model empirically the cross-country incidence of the financial crisis of 2008. Ours is an exploratory approach; we view it as a first step toward creating an international early-warning system, which necessarily includes both time-series and cross-sectional elements. Our objectives are: a) to determine whether the data patterns can be fitted within sample; and b) to provide 
preliminary evidence on which causes of the financial crisis seem to predict its ex post incidence across countries.

We conduct a non-structural exercise, using a "MIMIC" (Multiple-Indicator Multiple Cause) model, which we apply to a cross-sectional data set of 107 countries. Our MIMIC specification explicitly acknowledges that the severity of a financial crisis is a continuous, rather than a discrete phenomenon, and one that can only be observed with error. It treats the severity of the financial crisis as a latent variable, observed only imperfectly in terms of such 2008 manifestations as equity market collapses, exchange rate depreciations, recessionary growth, and declines in the perceptions of a country's creditworthiness. The MIMIC methodology (described in more detail below) simultaneously links these "indicators" of a financial crisis with potential "causes" of the crisis. In the process, we obtain estimates of the severity of each country's crisis experience, as well as estimates of the impact of potential causes of the crisis.

Our data analysis yields a plausible set of estimates for the incidence and severity of the crisis across countries. That is, we can model empirically the fact that Iceland and Estonia were hit more severely in 2008 than say China. However, we have less success in linking crisis severity to its causes (dated from 2006 and earlier). Many hypotheses have been advanced in the literature regarding potential causes of the 2008 credit crisis; few emerge empirically as robust predictors of the severity of the crisis. Indeed, we find that only one variable - the size of the equity market run-up prior to the crisis - is a robust predictor of crisis severity. ${ }^{5}$ While the performance of this variable is intuitive, we find it surprising that other equally plausible variables fail to perform well (such as the magnitude of real estate price appreciation or the quality of the regulatory environment). Succinctly, we can reasonably model the severity of the crisis across countries, but we are unable to link it empirically to country-specific causes. 
A successful early warning system must predict (out of sample) both the cross-country incidence of crises as well as their timing. Thus our analysis bodes poorly for the ability of early warning models to forecast future financial crises. After all, ours should be a (relatively) easy first step; we know now that a crisis took place in 2008, and which countries were affected.

There can be three reasons for our predictive failure, assuming that we have not missed or grossly mis-measured one or more important causes of the crisis. First, it might simply be the case that the causes of the 2008 crisis differ across countries. If the cause of each country's crisis is different, one would not expect to find any commonality when pooling the data across countries. Since the timing of the crisis coincided closely across countries, this "explanation" seems strained. Alternatively, the 2008 crisis might be the result of a truly global shock, so long as its incidence varied across countries in a way that is unrelated to the regulatory, financial, and macroeconomic "fundamentals" we consider. Finally, the shock might be a national one (plausibly originating in the United States) that spread contagiously across countries. We do not model international linkages between countries in our analysis, which could "explain" our poor findings. Under the last two interpretations, our negative results indicate that the susceptibility of a country to succumb to a common or contagious shock is unrelated to the fundamentals that we consider.

All these interpretations seem like ominous warnings for early-warning models. If the causes of the crises differ across countries, there is little hope of finding a common statistical model to predict them. The same holds if common or contagious shocks are critical but a country's ability to withstand a global or spreading shock is unrelated to fundamentals. We conclude that our negative results show that constructing a plausible statistical model that can predict financial crises (similar to that of 2008) will be challenging. 


\section{II: Determinants of the Crisis}

There has been little work on the 2008 crisis that seeks to understand its cross-country incidence. One exception is Ehrmann, et al (2009), who find a role for current accounts and foreign exchange reserves in determining equity portfolio returns for a cross section of countries, after conditioning for exposure to the United States. ${ }^{6}$ Still, most of the analysis has been conducted on a purely national basis, often analyzing only American data. In this section, we review the large literature that has already emerged concerning potential determinants of relative performance during the global financial crisis. Anticipating the empirical work done below, we organize our review by grouping together theories of the crisis' origin.

\section{Size and Income}

We start with size and income levels, both factors used in the literature as crisis correlates (e.g. Reinhart and Reinhart, 2009 and Calvo and Loo-Kung, 2009).

We condition on size throughout our analysis because it has been generally observed that smaller countries have fared poorly in the crisis. The importance of size was felt most strongly among smaller nations who had experienced exceptional economic growth and domestic credit expansion during the boom years. A notable example is Iceland, a country whose status as a global financial center left it facing liabilities far in excess of its gross domestic product after the

collapse. $^{7}$ However, a number of smaller countries with their own currencies also had exposed financial sectors large relative to their domestic governments and economies (Buiter and Sibert, 2008). Size is also negatively correlated with openness; smaller countries tend to be open to international trade. Small countries were thus also heavily exposed to the collapse of 
international trade and trade credit, other features of the 2008 crisis. $^{8}$ For such reasons, we always include the natural logarithm of a country's population in our analysis of potential causes of the 2008 crisis (data sources are described in an appendix).

We also condition on income, as measured by the (log-) level of real GDP per capita. The 2008 crisis hit developed and emerging-market economies alike. It might seem that richer countries had advantages over poorer ones in responding to the crisis. For instance, the ability of a government to assist troubled financial institutions credibly seems clearly a function of domestic wealth. Nevertheless, this ability may have been correlated with the degree of exposure that domestic private agents took during the boom years, leaving rich nations as or more vulnerable than those of lower income. We consider the matter to be an empirical one, and accordingly, we condition on income throughout.

We now turn to other potential causes of the financial crisis, beginning with regulatory and financial policy.

\section{Financial Policies}

The first major broad category of potential causes of the 2008 crisis that has drawn attention from the literature is the set of weaknesses exposed in national and international financial regulatory frameworks. Bernanke (2009) notes that the crisis revealed the need for improvement in supervisory practices and internal communication, particularly the need for maintaining strong risk-management practices in good times as well as bad.

Buiter (2007) points to a number of flaws in the financial system that existed at the peak of the boom. These include excessive securitization, as well as investors and regulators placing too much faith in the opinions of private rating agencies. Spence (2008) argues that the asset price bubble was fuelled by a combination of excessive leverage and a widespread 
underestimation of increased systemic risk. Coval et al, (2009) argue that the excessively high ratings received by structured instruments are attributable to the excessive confidence that rating agencies had in their own abilities to assess risk

Existing regulatory structures may also have encouraged "procyclicality" into lending behavior through the Basel capital requirements. Basel I contributed to the growth of securitization by assigning lower capital charges to securitized assets, thereby encouraging banks to move assets into off-balance sheet vehicles, Demirguc-Kunt and Serven, (2009). Coval et al, (2009) also argue that the process of securitization substitutes systematic risks for diversifiable risks. However, securitization could not have been the only source of regulatory weakness. Hall and Woodward (2009) point out that the United Kingdom lacked extensive securitization activity yet experienced a worse economic crisis than that in the United States.

In addition to its preferential treatment of securitized assets, regulatory frameworks may have encouraged risk taking through the (implicit) designation of larger financial institutions as "too big to fail." These guarantees likely encouraged these institutions to expose themselves to greater risk than they otherwise would have. Moreover, the guarantees themselves came to represent government liabilities as the likelihood increased that bailouts would be required, further raising systemic concerns and exacerbating the severity of a country's economic position, e.g. Demirguc-Kunt and Serven (2009).

In addition to formal regulatory weaknesses, Bernanke (2009) argues that flaws also existed in the structure of competition and the improper incentives for risk-taking in financial institutions. He called for reforms ensuring that bonuses and other forms of compensation aligned the incentives of employees with those of their institutions. Institutional changes along 
these lines have been highlights to proposed reforms of the global financial system under Basel II [Basel Committee on Banking Supervision (2009)]. Buiter (2009) argues that as the economic boom persisted, regulatory capture and corruption became commonplace.

It should be stressed that these regulatory weaknesses were not confined to the United States. Buiter (2007) faults the regulatory structure of the Financial Services Agency and deficient banking insolvency laws for throwing Britain's financial sector into disarray. He argues that the separation of power in Britain's financial regulatory institutions left the agency that had the best information about financial sector difficulties (the FSA) incapable of conducting lender of last resort activity. However, Gieve (2009) argues that there were benefits to getting insurance and securities dealing under the same regulator at a time when the lines between these activities was breaking down.

The deterioration in institutions also extended beyond the formal regulation of the financial system. Krugman noted that as the boom continued, the share of financial transactions outside the umbrella of traditional banking regulation increased. ${ }^{9}$ Many have also argued that the quality of corporate governance also deteriorated over the boom years; Buiter (2009) refers to a "... steady erosion in business ethics and moral standards." As in the case of poor financial regulation, as long as firms were increasing markedly in market valuation, there was little incentive for equity or other stakeholders to rein in the activities of corporations. The extent of poor practices was revealed only after the bubble burst.

While the crisis revealed weaknesses in the financial regulatory regime, technological advances in financial engineering exacerbated the process. In particular, asset securitization carved mortgage-backed (and other) securities into more-complicated structured products, 
leaving assets more opaque. Mishkin (2008) argues that advances in information technology and financial innovations contributed to a "democratization of credit" that initially brought benefits to consumers, but eventually contributed to the financial crisis. Trichet (2009a) notes that while securitization brought the potential to increase diversification and enhance the management of risk, in practice it also allowed loan originators to sell credit immediately after it had been extended, effectively eliminating the incentives for proper risk management.

Moreover, securitization reduced overall transparency by reducing incentives to collect and disseminate information about counterparty risk (Buiter, 2007). Another difficulty with securitization was that it broke the link between those who had originated the loan and those who were bearing the risk, reducing the incentives for loan originators to conduct proper due diligence prior to extending credit (De Michelis, 2009).

We wish to account (albeit imperfectly) for the quality of the regulatory regime in our empirics below. Accordingly, we introduce a number of measures of the regulatory regime commonly used in the literature. Our measures include a number of variables from the Economic Freedom of the World database (EFW) including Bank Ownership (the share of bank deposits held in privately owned banks), Foreign Bank Competition (the denial rate of foreign bank license applications), Interest Rate Controls/ Negative Real Interest Rate (which measures credit market controls), and finally Credit Market Regulation (a summary score on the quality of regulation in credit markets). As is the case for all the potential crisis causes we investigate, these data are dated from 2006 (or sometimes earlier). We also include a number of measures dated 2003 from the Barth, Caprio and Levine (2005) data set (hereafter "BCL"), including measures of Overall Capital Stringency, Ability to Take Prompt Corrective Action, a Capital 
Regulatory Index, Official Supervisory Power, Restructuring Power, and a measure of the Power to Declare Insolvency. ${ }^{10}$

\section{Financial Conditions}

At the end of the boom in 2008 many countries found themselves in precarious financial positions, in part because of regulatory policies, but also because of the natural "pro-cyclicality" of bank lending behavior. De Gregorio (2009) concludes that the ultimate cause of the crisis was increased fragility in the United States financial system. Brunnermeier (2009) also describes a decline in lending standards during the run-up to the crisis. Weak banks do not resist a financial crisis well.

Certain financial market practices exposed the banking sector to potential deep financial distress. For example, Cecchetti (2008) notes that banks typically maintained short-term balance sheets in interbank lending markets. This allowed them to adjust the size and composition of their assets quickly during normal periods. However, when these markets seized up, banks found themselves illiquid. Moreover, bank lending practices became riskier. Feldstein (2009) notes that mortgage loan contracts in America gradually evolved from 70 to 80 percent of appraised value at origination, to 90 to 100 percent. White (2008) argues that some of the expansion of sub-prime and other risky mortgages was policy-induced, encouraged by Congress' strengthening of the Community Reinvestment Act, the loosening of down-payment standards by the Federal Housing Administration, and pressure on lenders from the U.S. Department of Housing and Urban Development to extend mortgages to a broader set of potential borrowers. That is, not all of the weaknesses may have been unintentional. 
Weaknesses in the financial sector manifested themselves in a number of dimensions that left economies exposed when conditions began to turn. During the boom, many countries experienced dramatic increases in the extension of domestic credit, both for investment and consumption, and the leverage of firms and households exploded. With the abrupt decline in the terms of credit extension, consumers and firms found themselves in need of dramatic deleveraging, leading to declines in both of these important components of GDP (Boone, Johnson and Kwak, 2009).

Because we are interested in understanding the cross-country incidence of the crisis, we accordingly include a number of variables that measure the conditions of national financial sectors shortly before the crisis actually began. Of course, some of these variables are themselves outcomes of government policies, including the financial policies discussed above, and may therefore be endogenous to some of the policy variables listed above.

As measures of relative domestic credit growth, we include Private Sector Domestic Credit as a share of GDP, Domestic Bank Credit as a share of GDP, and a measure of the share of domestic credit consumed by the Private Sector. As measures of bank strength going into the crisis, we include Bank Liquid Reserves as a share of assets, the share of Non-Performing Loans, Bank Capital as a share of assets, and Bank Claims as a share of deposits.

\section{Asset Price Appreciation}

Every discussion of the causes of the global financial crisis includes the run-up in real estate values in the United States and elsewhere (e.g. Feldstein, 2009, and Teslik, 2009). Hall and Woodward (2009) claim that the collapse of spending on home building and the resulting recession was the "most important fact" about the American economy at the start of 2009. 
Feldstein (2008) argues that until housing prices stabilize, it will be impossible for the private sector to properly value mortgage-backed securities. Reinhart and Rogoff (2008) note that American housing price appreciation prior to this crisis exceeded those in the previous "Big Five" postwar crises. ${ }^{11}$ Noting parallels with Japan's experience, Shirakawa (2009) recalls the "irrational frenzy" that occurred in land prices in Japan prior to their collapse, and notes similarities among real estate values in Western economies prior to the 2008 crisis.

One reason that the real estate boom is perceived as a source of fragility is that it channeled investment away from more productive areas into "unproductive residential construction" (Buiter, 2009). Another is that as the housing market cooled, household balance sheets deteriorated and many homeowners found themselves with negative housing equity (Feldstein, 2009). U.S. Mortgage delinquencies have been highest in the areas that experienced the greatest rate of price appreciation during the boom (Doms, et al, 2007).

It is widely agreed that the magnitude of the real estate boom was increased by loose financial conditions. For example, Bernanke (2009a) notes that the housing boom was fueled in "large part" by a rapid expansion in mortgage lending. De Michelis (2009) notes that the boom in sub-prime lending coincided with the real estate boom. Mian and Sufi (2008) find that zip codes with high latent demand for housing experienced large decreases in mortgage denial rates between 2001 and 2005, even though these areas experienced poor economic performance over this period. This suggests that sub-prime mortgages facilitated the run-up in real estate prices in these areas. Moreover, Mayer, et al, (2009) note that mortgage defaults and delinquencies were particularly concentrated among mortgages that were classified as "subprime or near-prime." However, U.S. real estate appreciation was not exorbitant relative to other OECD countries, 
suggesting that sub-prime lending alone, alone cannot explain the run-up in real estate prices (De Michelis, 2009); this was exceptionally prevalent in the United States.

For all these reasons, run-ups in real estate prices are commonly considered important factors in determining relative economic vulnerability in the global financial crisis.

The bubble in real estate values was paralleled by a run-up in other asset prices, especially in equity. It is widely thought that these "bubbles" were fueled by easy monetary policy and an underestimation of underlying risks in financial markets (Frankel, 2008). Reinhart and Rogoff (2008) demonstrate that equity price appreciation in the United States was even more dramatic than appreciations experienced during the "Big Five" post-war debt crises, and speculate that the cause was the "extraordinary amount" of stimulus provided by the Federal Reserve during the run-up to the crisis. As global economic activity slowed and equity prices fell, those countries that had experienced the greatest increases in equity prices during the boom period found themselves most vulnerable.

We therefore include a number of measures of real estate and equity price appreciation. We include the Percentage Change in Real Estate Prices, based on data from the BIS and augmented by an Asia-specific study by Glindro, et al (2008). As measures of equity market appreciation, we include: Market Capitalization as a share of GDP; the value of Stocks Traded relative to GDP; and Stock Market Growth.

\section{International Imbalances}

Many countries built up precarious international financial positions over the boom years that became unsustainable when easy credit extension ceased (Buiter, 2009). The sources of these imbalances are controversial. Many observers, such as Buiter (2007) and Wolf (Teslik, 
2009), identify the efforts by Asian and oil-exporting governments to build up large currency reserves as a source of the major global imbalances and subsequent excessive asset price appreciation in the west.

This particularly includes China, which ran huge trade surpluses with developed countries and accumulated over $\$ 1$ trillion in foreign reserves. However, Buiter (2009) also argues that the western nations were complicit in fueling these current account deficits through lax macroeconomic policies. In fact, those who point to monetary policy in the United States as a prominent factor in causing the crisis often argue that the imbalances would have been there even with a more flexible Chinese exchange rate (e.g. Mohan, 2009). ${ }^{12}$

Fratzscher (2009) finds that countries with worse than average current account positions experienced greater than average exchange rate depreciations during 2008. He also finds that countries with larger than average liabilities towards the United States also suffered larger than average exchange rate depreciations that year. He conjectures that US investors in need of dollar liquidity were reluctant to roll those credit extensions over during the most turbulent period of the financial crisis.

Given a country's current account position, its ability to manage that position is likely to be a function of its "war chest" of international reserves. Obstfeld, et al (2009) find that inadequate holdings of foreign exchange reserves relative to estimated "required" levels based on their theoretical specification was an important predictor of exchange rate depreciation in 2008. Fratzscher (2009) finds that adequate holdings of foreign exchange reserves significantly affected the exchange rate experiences of countries in 2008. He finds that countries with below- 
average reserve holdings experienced a $23 \%$ average exchange rate depreciation against the dollar, while those with above-average holdings only experienced a 7\% depreciation on average.

We therefore include both measures of the severity of current account imbalances and the adequacy of holdings of foreign reserves. As measures of the external balance position, we include both stock and flow measures: the Net External Position, the Current Account (both measured as percentages of GDP, Debt Service as a percent of exports, External Debt as a percentage of gross national income, Gross Financing in International Capital Markets as a percent of GDP, and the Real Effective Exchange Rate (normalized to be 100 in the year 2000). As measures of the adequacy of foreign reserve holdings, we include Total Reserves as a percent of external debt, Short-Term Debt as a Percent of Reserves, Total Reserves over the Value of a Month of Imports, M2 as a percent of Total Reserves minus Gold, and M2 as a percent of Central Bank Foreign Assets.

\section{Macroeconomic Policies}

Many have blamed easy have blamed lax macroeconomic policies for exacerbating current account imbalances and fueling the boom. Taylor-Rule based simulations indicate that the Federal Funds rate was below levels consistent with a 2\% inflation target between 2003 and 2006, sometimes by as much as 200 basis points (e.g. White, 2008). However, this viewpoint is not universal. For example, Hall and Woodward (2009) argue that the easy monetary policy at the start of the decade represented "responsible" monetary policy to head off deflation rather than an "... irresponsible contribution to a housing bubble." 
In addition to expansionary monetary policy, others (e.g. De Long, 2009) point to the perception that the Federal Reserve stood ready to step in to support asset prices (the so-called Greenspan and Bernanke "puts") as a cause for excessive asset price appreciation.

Analysts have also pointed to lax fiscal policy as a source of vulnerability. Buiter (2009) argues that countries such as the United States and the United Kingdom pursued unsustainable fiscal deficits that exacerbated the expansion of current account deficits. Moreover, he argues that lax fiscal policy has resulted in a loss of fiscal credibility in government's capacity to address the global crisis. Large deficits have raised concerns that current expansionary fiscal policies will be resolved either by monetization or default. In turn, this concern has pushed up long-term interest rates, reducing the effectiveness of fiscal policy as a counter-cyclical instrument. Alternatively, some speculate that such concerns may encourage governments to resist fiscal easing, thereby exacerbating the economic downturns.

As measures of cross-sectional differences in monetary regimes, we include a dummy indicating if a country is a Currency Union member, the Aggregate GDP of a Country's Monetary Zone, a dummy indicating countries that are members of the European Union, but not the European Monetary Union, a dummy indicating of a country is an Inflation Targeter, M2 as a percent of GDP, and M3 as a percent of GDP. As measures of cross-sectional differences in fiscal policies, we include the Government Budget Surplus/Deficit as a share of GDP, the stock of Central Government Debt as a share of GDP, the stock of Total Debt as share of GDP, and the Debt Service Burden as a share of GDP. We also control for cross-country differences in macroeconomic conditions going into the crisis by including a measure of CPI Inflation and a measure of GDP Growth. ${ }^{13}$ 


\section{Institutional Factors}

We also search for the effects of institutional features across countries in crisis severity. Acemoglu, et al (2003) find that countries with inferior institutional features suffer from increased macroeconomic volatility, to the extent that after controlling for institutional differences, macroeconomic policy differences only play a limited role in explaining crosscountry volatility differences.

To control for institutional differences, we include the EFW index of Credit/Labor/Business Regulation, the Polity index, a measure of Constraints on the Executive (also taken from the Polity data set), a measure of Overall Economic Freedom, a dummy indicating a Common Law country, indices of Control of Corruption, Regulatory Quality, the quality of enforcement of the Rule of Law, Political Rights, Civil Liberties, and the EFW measures of Government Size, Security of Property Rights, and Sound Money Access.

\section{Geography}

Our final set of considerations is geographic; such features may have played a role in relative performance as well. Iceland's proximity to the United Kingdom and the Netherlands made it an attractive destination for British and Dutch depositors, perhaps contributing to the expansion of its financial sector (Danielsson, 2008). Similarly, Eastern Europe experienced waves of investment during the boom not enjoyed by more remote economies. While these investments initially promoted rapid expansion of these proximate economies, they left these countries more exposed to a reversal of fortune in the wake of a global "sudden stop" in credit extension. 
To control for geographic differences, we include the Log of Latitude, and dummies for East Asian countries, Central/Eastern Europe, Central Asian countries, Commodity Exporters, and English Speaking countries.

We now turn to empirical evidence concerning the causes and consequences of the 2008 financial crisis.

\section{III: Empirical Strategy}

We examine an international cross-section, using country-specific information. Thus we ignore linkages between countries almost completely; these would be relevant if the crisis spread "contagiously." However, even if the shocks that precipitated the crisis were common and/or spread contagiously, national fundamentals may help determine the actual incidence of the crisis across countries. Accordingly, we model the severity of the financial crisis as a function of the economic, political, and institutional characteristics of a country. ${ }^{14}$

\section{The Sample of Data}

We are interested in examining a broad cross-section of countries and territories. ${ }^{15} \mathrm{We}$ wish to include all the countries that have been dramatically affected by the crisis as well as a number of other countries that have not been affected as badly (as controls). Since the incidence of the crisis was notable among high-income countries, we include all of them as well as a large number of developing countries. In particular, we examine all countries with real GDP per capita of at least $\$ 10,000$ in 2003. To this set of countries, we add those with real GDP per 
capita of at least $\$ 4,000$ and a population of at least one million. ${ }^{16}$ We are left with a sample of 107 countries; their names are tabulated in an appendix. ${ }^{\mathbf{1 7}}$

\section{Identifying Cross-sectional Differences in Crisis Severity}

Identifying the incidence of a financial crisis (currency, asset, banking, or other) across countries is no simple matter, let alone determining its severity (e.g. Berg, et al, 2004). Any reasonable methodology should take into account the fact that potentially serious measurement error is inherently present.

We begin with a simple non-structural approach. In particular, we consider four observable indicators of the crisis, and model the incidence and severity of the crisis as being a latent variable that can be linked to these variables. When measuring these manifestations of the crisis, we restrict ourselves insofar as possible to data from 2008 (we sometimes use data from early 2009). ${ }^{18}$

Our first measure of the 2008 crisis is real GDP growth over 2008, as estimated by the Economic Intelligence Unit (EIU) in early March 2009. ${ }^{19}$ We also consider a broad range of financial variables covering stocks, bonds, and international finance. Above and beyond growth, we include: 1) the percentage change in a broad measure of the national stock market over the 2008 calendar year (collected from national sources); 2) the percentage change in the SDR (multilateral) exchange rate over 2008 (measured as the domestic currency price of a Special Drawing Right and taken from the IMF's International Financial Statistics); and 3) the change in the country credit rating from Institutional Investor. The latter are ratings created by Institutional Investor that rank 177 countries on a scale between 0 and 100 where 100 represents the least likelihood of default (as of March 2009, Switzerland was the most highly rated country 
with a score of 94.0, while Zimbabwe brought up the rear at 4.6). ${ }^{20}$ Institutional Investor publishes these rankings biannually in March and September; we use the change between March 2008 and March 2009. ${ }^{21}$ We also use an analogue from Euromoney for sensitivity analysis. Our four measures of the consequences/manifestations of the crisis are presented for forty key countries of interest in Table 1 . The four indicators are not particularly tightly related, as shown by the correlation matrix of Appendix Table A3.

How should these four factors be combined appropriately? Perhaps the most straightforward way to proceed is to extract a common component from the four variables using purely statistical techniques and examine its characteristics. Accordingly, we estimate a single factor using conventional factor analysis; estimates for the "top-40" countries are presented in Table 2. Our default factor is estimated using the method of principal factors on our four variables, with regression scoring (because of missing data, the estimates are actually derived from 85 observations). ${ }^{22}$ Three variants of the factor are also included for sensitivity analysis: one replaces the change in the Institutional Investor country credit rating with the analogue from Euromoney; another drops the exchange rate (since some countries use the exchange rate as an objective or instrument of monetary policy); and a final variant estimates the factor via maximum likelihood.

Our four different variables measuring the severity of the crisis are strongly positively correlated with each other and deliver broadly similar rankings. A number of countries have been particularly hard hit by the crisis, and these show up at the top of our list. These include Iceland most especially; Iceland's fall from grace was particularly striking and has been much noted (as of March 2009, Icelandic GDP was forecast by the EIU to shrink by $12 \%$ in 2009). However, a number of other countries have also been hit hard including the Baltic countries 
(Estonia, Latvia and Lithuania), the Ukraine, Ireland, Korea, New Zealand, the UK, and Hungary. All these countries appear towards the top of our list of crisis countries; the plausibility of the extreme cases lends credibility to this exercise.

While most of the results in Table 2 seem plausible, our cross-section also includes some surprising results. For instance, we find Japan - whose GDP decline was particularly severe in the $4^{\text {th }}$ quarter of 2008 and the first quarter of 2009 - is characterized as relatively unaffected by the global crisis. In part, this performance is likely explained by the appreciation of the yen, an idiosyncratic event associated with the unwinding of the yen "carry trade" that was part of the financial crisis. While one can explain such phenomena, we interpret such mis-characterizations not as outliers that should be expunged, but as warnings that should make one cautious. In practice, even determining which countries have been more or less affected by crises can rarely be determined by a simple mechanistic manipulation of standard economic variables.

\section{Linking Incidence and Causes: First Pass}

Given an estimate of the incidence of the crisis across countries, one can then attempt to link crisis incidence to its potential causes. We do this by using a host of possible determinants of the crisis related to the voluminous literature cited above. To avoid endogeneity issues as much as possible with such an exercise, as well as speak to the potential performances of early warning models, we restrict ourselves to data from 2006 and earlier for our crisis causes.

We begin with a simple examination of whether our crude measures of crisis incidence can be linked to the size and income of a country. ${ }^{23}$ Figure 1 presents scatter-plots of our four different measures of crisis incidence (on the ordinate); each is graphed against the natural logarithm of 2006 population (on the abscissa; this is taken from the World Bank's World 
Development Indicators). Our default measure is portrayed in the top-left graph, and shows only a cloud of data with a small negative relationship between crisis intensity and size (Iceland is visible as a small country hit hard by the crisis). The other three variants include a nonparametric data smoother, and also show a slight negative correlation between crisis incidence and size. That is, the intensity of the crisis does not seem to be strongly linked to country size.

By way of contrast, a country's income is more strongly (negatively) correlated with crisis intensity. Figure 2 shows that the negative relationship is present for all four variants of the crisis measure, measuring income with the log of real 2006 GDP per capita (the relationship is somewhat weaker when the factor is estimated with maximum likelihood). ${ }^{24}$

The impressions given in Figures 1 and 2 are graphical in nature and accordingly informal. However, they can easily be corroborated more rigorously with standard statistical techniques. Table 3 provides estimates of OLS coefficients from a regression of our default factor on the natural logarithms of 2006 population and real income per capita; standard errors robust to the presence of heteroskedasticity are presented parenthetically. Size has a negligible effect on factor incidence, but income seems to have a sizeable negative effect which is significantly different from zero at conventional confidence levels. This conclusion does not depend on the exact way that the factor is estimated, and is consistent with the graphical evidence of Figures 1 and 2. This tentative evidence points toward an income effect on crisis incidence but no clear size effect. Nevertheless, we continue to include both effects as controls in our analysis below.

A different tack on these issues is to examine the effect of income and regional groupings. The World Bank splits countries into eight bins, and we use these to create simple 
binary variables. There are two groups of high-income countries, OECD and non-OECD. Developing countries are divided into six regional groupings: East Asia and Pacific; Eastern Europe and Central Asia; Latin America and the Caribbean; South Asia; Sub-Saharan Africa; and the Middle East and North Africa. We drop the last region and add seven appropriately constructed dummies to our regressions in place of population and size. These show much the same pattern. First, income matters negatively: the OECD dummy is quite negative, the coefficient on high-income non-OECD less so, and not all the developing country coefficients are statistically significant. The estimates indicate that Eastern Europe and Central Asian countries have been quite adversely affected by the crisis. We also obtain statistically significant negative coefficients for the Sub-Saharan countries and the developing South-Asian countries.

One way to proceed next would be to run regressions of our extracted factor(s) on a host of possible causes of the crisis (controlling for size and income). For instance, we include a measure of the buildup in the stock market in the final column at the extreme right of Table 3 (it has a statistically insignificant coefficient). However, given that we have a large number of potential causes and indicators without a directly observable measure of the crisis, we prefer to model these features collectively and explicitly with a Multiple Indicator Multiple Cause (MIMIC) model.

\section{The MIMIC Model}

The Multiple Indicators Multiple Causes (MIMIC) model was introduced to econometrics by Goldberger (1972). Aigner et al (1984) provide a general introduction to latent variable models, while Gertler (1988) has a nice exposition and empirical application; we follow Gertler's exposition below. 
The MIMIC model consists of two sets of equations:

$$
\begin{aligned}
& y_{i, j}=\beta_{j} \xi_{i}+v_{i} \\
& \xi_{i}=\gamma_{k} x_{i, k}+\zeta_{i}
\end{aligned}
$$

where: $\mathrm{y}_{\mathrm{i}, \mathrm{j}}$ is an observation on crisis indicator $\mathrm{j}$ for country $\mathrm{i}, \mathrm{x}_{\mathrm{i}, \mathrm{k}}$ is an observation for potential crisis cause $\mathrm{k}$ for country $\mathrm{i}$; $\xi_{\mathrm{i}}$ is a latent variable representing the severity of the crisis for country $\mathrm{i}$ (or lack thereof in our case); $\beta$ and $\gamma$ are vectors of coefficients, and $\nu$ and $\zeta$ are wellbehaved disturbances. ${ }^{25}$ Equation (1) links J consequences and manifestations of the crisis (denoted by y) to the unobservable measure of crisis severity. In practice, we model this measurement equation using our $(J=4)$ indications of the crisis (the 2008 national changes in: a) real GDP, b) the stock market, c) the credit rating, and d) the exchange rate). The second equation models the determination of the crisis as a function of $K$ causes (x's, dated 2006 or earlier).

By substituting (2) into (1), we can derive a model which is no longer a function of the latent variable $\xi$. This MIMIC model is a system of $\mathrm{J}$ equations with right-hand-sides restricted to be proportional to each another. These proportionality restrictions constrain the structure to be a "one-factor" model of the latent variable; with the addition of a normalization, they achieve identification of the parameters in (1) and (2). One of the features of the MIMIC model is that it explicitly incorporates measurement error about a key variable - the incidence and severity of the crisis - in a non-trivial and plausible way. ${ }^{26}$ Indeed, this is one of the chief attractions of the MIMIC model to us. ${ }^{27}$ 
We estimate our MIMIC models in STATA with GLLAMM; Rabe-Hesketh et al (2004a, b) provide further details. The iterative estimation technique begins with adaptive quadrature which is followed by Newton-Raphson. ${ }^{28}$ We normalize and achieve identification by imposing a factor loading of unity on the stock market change. ${ }^{29}$

In Table 4 we report estimates of $\gamma$ when we include only the logs of 2006 population and real GDP per capita as potential causes in (2); it is thus roughly analogous to Table 3 . Following Table 3, we also provide sensitivity analysis by using three different versions of our latent variables. We include our four default indicators as measures of the crisis (the same as those used in Table 3 and tabulated in Table 1). Using a MIMIC model, we estimate our latent variable from the four underlying crisis indicators and simultaneously link it to size and income as causes of the crisis; we tabulate estimates of the impact of size and income on this latent variable in Table 4. These results mirror those from the factor analysis of Table 3. The other two measures are variants for sensitivity analysis: one replaces the Institutional Investor country credit rating with its analogue from Euromoney while the second drops the exchange rate indicator. It is reassuring to see that size has no significant impact on the incidence of crises across countries, while income has a significantly negative impact. With this robustness check passed, we proceed on to investigate the cross-country determinants of the financial crisis.

\section{IV: Causes of the Financial Crisis}

We add each of our potential causes to the default MIMIC model of Table 4 one by one, and report the estimates in Table 5, retaining size and income as causes throughout. Thus the top-left cell in Table 5 is the $(\gamma)$ coefficient for the effect of private bank ownership on the latent 
variable of crisis incidence $(\xi)$. As with all other cells in the column, the estimate is taken from our default MIMIC model; four crisis indicators are used to model $\xi$, while size and income are included as causes ( $x$ 's), but not recorded so as to conserve on space. ${ }^{30}$ Thus each row in the column tabulates the effect of adding a single extra cause to our MIMIC model, conditional on including size and income. ${ }^{31,32}$

We also include in Table 5 four other columns of sensitivity analysis. Each is constructed analogously to our column of default results, but perturbs the methodology in some way so as to show the sensitivity of our results. The first column to the right of the default uses the Euromoney country credit ranking in place of that from Institutional Investor, while the second drops the exchange rate change as a crisis indicator. Another uses a different MIMIC model estimator (replacing adapative quadrature with Gauss-Hermite quadrature); a fourth substitutes the income and regional dummy variables of Table 3 in place of the continuous measures of $(\log )$ population and income.

The results are disappointing and weak in the sense that relatively few of the potential causes we investigate have a statistically significant impact on crisis incidence (conditional, as always, on size and income effects). For instance, countries that have experienced a run-up in real estate prices are often viewed as those that have suffered most severely in the crisis. However, when we include the percentage change in real estate prices between 2003 and 2006 as a potential cause of the crisis, it does not have an effect that is statistically different from zero at conventional levels. ${ }^{33}$ The same is true of almost all of the (over sixty) additional causes that we add in the remainder of the table. 
It should be stressed that this observed weakness is not simply an artifact of the MIMIC framework. As an example, Figure 3a plots one of our measures of the adequacy of the financial regulatory framework - the capital regulatory index of Barth, Caprio and Levine (2003) - against each of the four crisis indicator variables. Regulatory conditions are commonly cited as determinants of the relative performance of the exposure of countries to the economic crisis. However, even in a simple scatter plot without any control variables, it is clear that there is no systematic relationship between this commonly-cited causal variable and our crisis indicators. Indeed, only one of the scatter plots displays a positive correlation between the measure and subsequent performance, and this relationship is completely insignificant. ${ }^{34}$

We obtain similar results for most of the other variables that we investigate as potential crisis determinants; Figures $3 \mathrm{~b}-3 \mathrm{~h}$ are analogues to Figure $3 \mathrm{a}$ that portray a number of other potentially important crisis determinants. With the exception of the equity market appreciation variable (portrayed in Figure 3b) which exhibits its expected negative correlation, there appears to be little or no correlation between our measures of crisis determinants and crisis manifestations.

Figure 4 repeats this exercise but graphs twelve potential causal variables against our estimated latent crisis variable (not the four underlying indicators of the crisis). We again see modest negative correlations for the log of real GDP per capita and equity market appreciations, but little else. In particular, nations' current account positions, which entered positively in the univariate specifications with regional dummies excluded, are now insignificant as well. Possible exceptions include our measures of financial conditions, including domestic bank credit (relative to GDP) and bank capital (as a percent of total assets); both exhibit modest negative relationship with our latent variable. 
There are a few exceptions to our generally weak results. Countries that experienced a large run-up in the stock market (measured relative to output) between 2003 and 2006 were more likely to be hit by the 2008 crisis. Countries with larger current account deficits and fewer reserves (measured relative to short-term debt) were also more vulnerable. There is weaker evidence that countries with high credit growth and a more levered banking sector are also associated with the severity of the crisis. We also know that some of the Eastern European and Baltic countries have been hard-hit, and this is apparent when we include geographic dummies.

Nevertheless, few of our potential causes have strong effects that are robust across slightly different specifications of our MIMIC model. For instance, a dummy variable that identifies large commodity exporters is typically statistically insignificant. ${ }^{35}$ Our results clearly suggest that measurable pre-existing conditions across countries had little common impact on the relative severity of these countries' crisis experiences, as observed within our MIMIC framework.

It may be the case that the results in Table 5 are weak because they add causes to our basic MIMIC model one by one rather than simultaneously. While we are skeptical of this interpretation, we investigate it further in Table 6. This takes our default MIMIC model and adds a set of eleven causes simultaneously (above and beyond size and income). Unfortunately our results here are even worse than those obtained in Table 5; almost none of the coefficients are statistically significant, with the exception of the stock market variable and the CentralEastern Europe/Central Asia dummy. Both of these enter at statistically significant levels when the short-term debt/reserves variable is excluded. ${ }^{36}$ 
Overall, it must be concluded that the variables we investigate as potential determinants of the financial crisis of 2008 deliver only disappointing results. While many seem like they should be empirically relevant determinants, in practice they are simply not closely linked to crisis severity. These results indicate that creating an empirically viable early warning system will be challenging; such a system must conquer all the problems we faced, while also being able to predict the timing of future crises out of sample.

\section{V: Conclusion}

This paper examines the causes and consequences of the global financial crisis of 2008 . We use a MIMIC (Multiple Indicator Multiple Cause) model that exploits a cross-section of aggregate data from 107 countries. Our approach explicitly acknowledges that the severity of the crisis is a continuous variable that is only observed with error. We investigate the importance of a broad set of potential causes of the crisis in a relatively unstructured empirical specification, thereby allowing the data to speak as loudly as possible. Our reasoning is that success in a cross-sectional approach is a necessary (but far from sufficient) condition for any reliable early warning system, which must also confront additional problems such as predicting the timing of crises out of sample. We examine a large number of potential explanatory variables for the crisis that have been discussed in the literature; these cover a host of "fundamentals" including the regulatory framework, financial conditions, and the macroeconomic, institutional, and geographic features of a country. However, we found almost none of our posited variables seem to be statistically significant determinants of crisis severity; they simply do not account for the incidence of the crisis across countries. While we can model 
the incidence of the crisis reasonably well, we have been unable to link the severity of the crisis across countries to its causes.

One potential reason why our results are weak may be that we have poor measures of the fundamental determinants of the crisis, or of its incidence. Our data on crisis manifestations were collected in the early Spring of 2009, and may not adequately capture the full extent of the financial crisis. Still, our measures of crisis incidence and severity seem intuitive and reasonable; our problem seems to be explaining the crisis of 2008, not measuring it.

However, there are two other possible reasons for the weakness of our results, both of which bode poorly for the performance of early warning models. First, a potentially serious problem with our approach is that we model the cross-country incidence of the crisis as being due to national characteristics. This is inappropriate if the fundamental causes of the crisis are international in nature, for instance because the crisis spreads contagiously or is the result of a common shock. Still, our negative results imply that even if the crisis was transmitted across countries through one or more channels, its incidence seems unrelated to national fundamentals.

Alternatively, a plausible interpretation for our weak results is that it is quite difficult to model the determinants of crises. Perhaps the causes of the 2008 crisis were idiosyncratic and lack a common explanation; perhaps the linkages exist but are opaque and cannot be easily quantified with observable data. Essentially what we have shown here is that the cross-country causes of the financial crisis are hard to pin down with standard econometric techniques.

Negative results like ours in a cross-section make us dubious about the accuracy of an early warning model that will have all the problems we have encountered and, in addition, the problem of predicting the timing of future crises. So, with the caveat that the data we use 
represent only early evidence concerning the manifestations of the global financial crisis, we conclude that our paper provides an early warning that model-based early warning systems are unlikely to predict future crises accurately. 
Table 1: Consequences and Manifestations of the Crisis, Top 40 Countries

\begin{tabular}{|c|c|c|c|c|}
\hline \% Changes, 2008: & Real GDP & II Rating & Stock Market & Price of SDR \\
\hline Iceland & -4.7 & -32.5 & -90.0 & 90.0 \\
\hline Ukraine & 2.1 & -12.1 & -74.3 & 48.6 \\
\hline Estonia & -2.8 & -9.4 & -63.0 & 1.7 \\
\hline Argentina & 6 & -13.6 & -49.8 & 6.9 \\
\hline Latvia & -4.6 & -8.3 & -55.1 & -.3 \\
\hline Ireland & -2.8 & -7.8 & -66.1 & 3.1 \\
\hline Korea & 2.6 & -7.3 & -40.7 & 30.9 \\
\hline New Zealand & -.9 & -5.4 & -37.4 & 30.4 \\
\hline UK & .7 & -5.5 & -31.5 & 33.9 \\
\hline Hungary & .4 & -7.6 & -53.2 & 6.1 \\
\hline Kazakhstan & 3.2 & -8.9 & -65.7 & -2.1 \\
\hline Lithuania & 3.7 & -7.9 & -66.0 & 1.3 \\
\hline Australia & 2.1 & -4.5 & -43.0 & 24.0 \\
\hline South Africa & 3.1 & -4.7 & -26.3 & 33.2 \\
\hline Turkey & 1.5 & -3.0 & -52.4 & 27.6 \\
\hline Bulgaria & 5.4 & -6.6 & -79.7 & 1.6 \\
\hline Italy & -.6 & -4.7 & -49.5 & 3.1 \\
\hline Sweden & .5 & -3.5 & -42.0 & 18.7 \\
\hline Russia & 5.6 & -4.8 & -64.9 & 16.7 \\
\hline Norway & 1.5 & -2.1 & -52.6 & 26.1 \\
\hline Romania & 7.7 & -5.9 & -70.5 & 12.5 \\
\hline Austria & 1.6 & -4.6 & -61.2 & 3.1 \\
\hline Portugal & 0 & -4.3 & -51.2 & 3.1 \\
\hline Canada & .6 & -3.0 & -35.0 & 20.8 \\
\hline Greece & 3 & -4.6 & -65.5 & 3.1 \\
\hline Mexico & 1.5 & -3.6 & -24.1 & 21.4 \\
\hline United States & 1.2 & -5.8 & -38.5 & -2.5 \\
\hline Belgium & 1.1 & -3.8 & -53.8 & 3.1 \\
\hline Croatia & 2.2 & -3.7 & -67.1 & .8 \\
\hline Namibia & 3.3 & -1.1 & -40.1 & 33.2 \\
\hline Spain & 1.1 & -4.2 & -39.4 & 3.1 \\
\hline Luxembourg & .6 & -2.6 & -59.5 & 3.1 \\
\hline Denmark & -.9 & -2.6 & -48.6 & 1.5 \\
\hline Singapore & 1.2 & -3.8 & -48.9 & -2.7 \\
\hline Swaziland & 2.7 & -2.6 & 3.9 & 33.2 \\
\hline Finland & 1.4 & -2.6 & -53.4 & 3.1 \\
\hline Japan & -.5 & -5.7 & -42.1 & -22.4 \\
\hline France & .7 & -2.6 & -42.7 & 3.1 \\
\hline Netherlands & 2 & -2.5 & -52.3 & 3.1 \\
\hline Thailand & 3 & -3.5 & -47.6 & 1.3 \\
\hline Poland & 4.8 & -1.5 & -51.1 & 18.6 \\
\hline
\end{tabular}

Estimates of GDP 2008 Growth from Economist Intelligence Unit; change in country credit ratings between 3/2007 and 3/2008 from Institutional Investor; 2008 percentage change in stock market from major market indices; 2008 change in domestic price of SDR from IFS. 
Table 2: First Principal Factor for Top 40 Countries

\begin{tabular}{|c|c|c|c|c|}
\hline & Default & $\begin{array}{c}\text { EuroMoney } \\
\text { not II }\end{array}$ & $\begin{array}{c}\text { Drop } \\
\text { Exchange Rate }\end{array}$ & $\begin{array}{c}\text { MLE } \\
\text { Estimate }\end{array}$ \\
\hline Iceland & -5.5 & -3.3 & -4.2 & -6.7 \\
\hline Ukraine & -1.9 & -.7 & -1.4 & -2.0 \\
\hline Estonia & -1.1 & -2. & -1.4 & -1.4 \\
\hline Argentina & -1.1 & .4 & -.9 & -2.3 \\
\hline Latvia & -1.0 & -1.5 & -1.3 & -1.1 \\
\hline Ireland & -1.0 & -1.2 & -1.2 & -1.0 \\
\hline Korea & -.9 & -.1 & -.4 & -.9 \\
\hline New Zealand & -.8 & -1.0 & -.5 & -.5 \\
\hline UK & -.7 & -.8 & -.3 & -.5 \\
\hline Hungary & -.7 & -1.2 & -.8 & -1.0 \\
\hline Kazakhstan & -.7 & .0 & -.9 & -1.3 \\
\hline Lithuania & -.6 & -.6 & -.7 & -1.0 \\
\hline Australia & -.5 & -.5 & -.2 & -.3 \\
\hline South Africa & -.5 & -.1 & .1 & -.3 \\
\hline Turkey & -.5 & -.2 & -.2 & .1 \\
\hline Bulgaria & -.4 & .0 & -.6 & -.7 \\
\hline Italy & -.4 & -.8 & -.5 & -.3 \\
\hline Sweden & -.4 & -.7 & -.2 & -.0 \\
\hline Russia & -.3 & .5 & -.2 & -.3 \\
\hline Norway & -.3 & -.4 & -.1 & .3 \\
\hline Romania & -.3 & .4 & -.3 & -.6 \\
\hline Austria & -.3 & -.6 & -.5 & -.3 \\
\hline Portugal & -.3 & -.8 & -.5 & -.2 \\
\hline Canada & -.3 & -.6 & -.1 & .1 \\
\hline Greece & -.3 & -.2 & -.4 & -.3 \\
\hline Mexico & -.2 & -.3 & .1 & -.1 \\
\hline United States & -.2 & -.3 & -.4 & -.5 \\
\hline Belgium & -.2 & -.6 & -.4 & -.1 \\
\hline Croatia & -.2 & -.2 & -.4 & -.1 \\
\hline Namibia & -.1 & .8 & .3 & .5 \\
\hline Spain & -.1 & -.6 & -.2 & -.2 \\
\hline Luxembourg & -.1 & -.7 & -.4 & .2 \\
\hline Denmark & -.1 & -.7 & -.3 & .2 \\
\hline Singapore & -.1 & -.2 & -.3 & -.1 \\
\hline Swaziland & -.0 & .2 & .6 & .2 \\
\hline Finland & -.0 & -.4 & -.2 & .2 \\
\hline Japan & -.0 & -.4 & -.5 & -.5 \\
\hline France & .0 & -.6 & -.1 & .2 \\
\hline Netherlands & .0 & -.4 & -.1 & .2 \\
\hline Thailand & .0 & -.1 & -.1 & -.0 \\
\hline Poland & .1 & .1 & .2 & .4 \\
\hline
\end{tabular}

Default estimate is of first principal factor from 2008 growth, Institutional Investor country credit rating change, stock market change and exchange rate change, estimated with principal factors (not rotated), cross-section of 85 observations; eigenvalue $=1.33$ ( 
Table 3: Regressions of Principal Factor on Size and Income

\begin{tabular}{|c|c|c|c|c|c|c|}
\hline Crisis Measure: & Default & EuroM & No ER & MLE & Default & Default \\
\hline Log (2006 Population) & $\begin{array}{l}.01 \\
(.08)\end{array}$ & $\begin{array}{c}.01 \\
(.05)\end{array}$ & $\begin{array}{l}-.02 \\
(.06)\end{array}$ & $\begin{array}{l}-.00 \\
(.10)\end{array}$ & & $\begin{array}{c}.03 \\
(.08)\end{array}$ \\
\hline $\begin{array}{l}\text { Log ( } 2006 \text { Real GDP per } \\
\text { capita) }\end{array}$ & $\begin{array}{l}-.28 * * \\
(.08)\end{array}$ & $\begin{array}{c}-.44 * * \\
(.08)\end{array}$ & $\begin{array}{l}-.37 * * \\
(.07)\end{array}$ & $\begin{array}{l}-.26^{* *} \\
(.10)\end{array}$ & & $\begin{array}{c}-.38 * * \\
(.10)\end{array}$ \\
\hline OECD Dummy & & & & & $\begin{array}{c}-1.08 * * \\
(.24) \\
\end{array}$ & \\
\hline $\begin{array}{l}\text { High-Income, non- } \\
\text { OECD Dummy }\end{array}$ & & & & & $\begin{array}{l}-.22 * \\
(.09) \\
\end{array}$ & \\
\hline $\begin{array}{l}\text { Developing East Asia, } \\
\text { Pacific Dummy }\end{array}$ & & & & & $\begin{array}{l}-.13 \\
(.16)\end{array}$ & \\
\hline $\begin{array}{l}\text { Developing Eastern } \\
\text { Europe, Central Asia } \\
\text { Dummy }\end{array}$ & & & & & $\begin{array}{l}-.93 * * \\
(.19)\end{array}$ & \\
\hline $\begin{array}{l}\text { Developing Latin } \\
\text { American, Caribbean } \\
\text { Dummy }\end{array}$ & & & & & $\begin{array}{l}-.23 \\
(.14)\end{array}$ & \\
\hline $\begin{array}{l}\text { Developing South Asia } \\
\text { Dummy }\end{array}$ & & & & & $\begin{array}{c}-.17 * * \\
(.03)\end{array}$ & \\
\hline $\begin{array}{l}\text { Developing Sub-Saharan } \\
\text { Africa Dummy }\end{array}$ & & & & & $\begin{array}{c}-.58 * * \\
(.15)\end{array}$ & \\
\hline $\begin{array}{l}\text { Stock Market Growth, } \\
\text { 2003-6 }\end{array}$ & & & & & & $\begin{array}{l}-.23 \\
(.12)\end{array}$ \\
\hline
\end{tabular}

Coefficients, with robust standard errors in parentheses. Coefficients significantly different from zero at $.05(.01)$ significance level marked by one (two) asterisk(s).

Regressand is first factor (largest eigenvalue) from default specification. Intercept included but not recorded. 85 observations for default factor without stock market growth.

Table 4: The Effect of Size and Income in the MIMIC Model

\begin{tabular}{|l|c|c|c|}
\hline & Default & $\begin{array}{c}\text { Euromoney instead of } \\
\text { Institutional Investor }\end{array}$ & $\begin{array}{c}\text { Drop SDR Exchange } \\
\text { Rate }\end{array}$ \\
\hline Log(2006 Population) & -.98 & -1.05 & -2.08 \\
& $(.95)$ & $(.98)$ & $(1.12)$ \\
\hline Log(2006 Real GDP & $-7.79^{* *}$ & $-7.80^{* *}$ & $-10.1^{* *}$ \\
per capita) & $(2.44)$ & $(2.46)$ & $(2.66)$ \\
\hline
\end{tabular}

Coefficients, with standard error displayed in parentheses. Coefficients significantly different from zero at .05 (.01) significance level marked by one (two) asterisk(s).

Each column represents MIMC estimation on cross-section. Default: 4 consequences (2008 change in Stocks, 2008 Growth, 1-year change in Institutional rating, 2008 Exchange Rate change), fixed loading on stocks. Adaptive quadrature estimation. 
Table 5: Adding Causes to the MIMIC Model, One by One

\begin{tabular}{|c|c|c|c|c|c|}
\hline Extra Cause & Default & $\begin{array}{c}\text { Euromoney, } \\
\text { not II }\end{array}$ & $\begin{array}{c}\text { Drop } \\
\text { Exchange Rate }\end{array}$ & $\begin{array}{c}\text { Different } \\
\text { Estimator }\end{array}$ & $\begin{array}{c}\text { Region/Income } \\
\text { Dummies }\end{array}$ \\
\hline \multicolumn{6}{|l|}{ Financial Policies } \\
\hline $\begin{array}{c}\text { Overall Capital } \\
\text { Stringency, } 2003\end{array}$ & $\begin{array}{c}1.87 \\
(1.40)\end{array}$ & $\begin{array}{c}1.26 \\
(1.31)\end{array}$ & $\begin{array}{c}.82 \\
(1.35)\end{array}$ & $\begin{array}{c}1.04 \\
(1.22)\end{array}$ & $\begin{array}{c}1.00 \\
(1.25)\end{array}$ \\
\hline $\begin{array}{l}\text { Capital Regulatory } \\
\text { Index, } 2003\end{array}$ & $\begin{array}{c}1.19 \\
(1.25)\end{array}$ & $\begin{array}{c}.78 \\
(1.42)\end{array}$ & $\begin{array}{c}.84 \\
(1.19)\end{array}$ & $\begin{array}{c}.51 \\
(1.26)\end{array}$ & $\begin{array}{c}-.55 \\
(1.11)\end{array}$ \\
\hline $\begin{array}{l}\text { Official Supervisory } \\
\text { Power, } 2003\end{array}$ & $\begin{array}{l}.62 \\
(.61)\end{array}$ & $\begin{array}{l}-.0006 \\
(.0010)\end{array}$ & $\begin{array}{l}.13 \\
(.61)\end{array}$ & $\begin{array}{l}.65 \\
(.51)\end{array}$ & $\begin{array}{l}-.0004 \\
(.0007)\end{array}$ \\
\hline $\begin{array}{l}\text { Ability to Take Prompt } \\
\text { Corrective Action, } 2003\end{array}$ & $\begin{array}{l}.70 \\
(.91) \\
\end{array}$ & $\begin{array}{l}.58 \\
(.81) \\
\end{array}$ & $\begin{array}{l}.16 \\
(.87) \\
\end{array}$ & $\begin{array}{l}.66 \\
(.78) \\
\end{array}$ & $\begin{array}{c}1.57 * * \\
(.54)\end{array}$ \\
\hline $\begin{array}{l}\text { Restructuring } \\
\text { Power, } 2003\end{array}$ & $\begin{array}{c}1.11 \\
(2.41) \\
\end{array}$ & $\begin{array}{c}.98 \\
(2.40) \\
\end{array}$ & $\begin{array}{c}.68 \\
(2.26) \\
\end{array}$ & $\begin{array}{c}1.85 \\
(1.94) \\
\end{array}$ & $\begin{array}{c}2.01 \\
(2.22) \\
\end{array}$ \\
\hline $\begin{array}{c}\text { Declaring Insolvency } \\
\text { Power, } 2003\end{array}$ & $\begin{array}{l}-1.65 \\
(3.06)\end{array}$ & $\begin{array}{l}-1.70 \\
(3.05)\end{array}$ & $\begin{array}{l}-1.84 \\
(2.95)\end{array}$ & $\begin{array}{c}-.34 \\
(3.71)\end{array}$ & $\begin{array}{c}-.25 \\
(2.80)\end{array}$ \\
\hline $\begin{array}{c}\text { Credit Market } \\
\text { Regulation, } 2006\end{array}$ & $\begin{array}{c}.35 \\
(2.44) \\
\end{array}$ & $\begin{array}{c}.65 \\
(2.47) \\
\end{array}$ & $\begin{array}{c}1.38 \\
(2.59) \\
\end{array}$ & $\begin{array}{c}.45 \\
(2.31) \\
\end{array}$ & $\begin{array}{c}3.74 \\
(2.16) \\
\end{array}$ \\
\hline $\begin{array}{c}\text { Private Bank } \\
\text { Ownership, } 2006\end{array}$ & $\begin{array}{c}.04 \\
(.94) \\
\end{array}$ & $\begin{array}{l}.11 \\
(.95)\end{array}$ & $\begin{array}{c}.30 \\
(1.12) \\
\end{array}$ & $\begin{array}{l}.04 \\
(.95) \\
\end{array}$ & $\begin{array}{l}1.38 \\
(.84) \\
\end{array}$ \\
\hline $\begin{array}{c}\text { Foreign Bank } \\
\text { Competition, 2006 }\end{array}$ & $\begin{array}{c}.81 \\
(1.63)\end{array}$ & $\begin{array}{c}.87 \\
(1.64)\end{array}$ & $\begin{array}{c}1.77 \\
(1.69)\end{array}$ & $\begin{array}{c}1.05 \\
(1.49)\end{array}$ & $\begin{array}{c}1.13 \\
(1.52)\end{array}$ \\
\hline $\begin{array}{l}\text { Interest Rate Controls/negative } \\
\text { real interest rate, } 2006\end{array}$ & $\begin{array}{c}.72 \\
(2.82)\end{array}$ & $\begin{array}{c}.83 \\
(2.86)\end{array}$ & $\begin{array}{c}.48 \\
(3.08)\end{array}$ & $\begin{array}{c}-.55 \\
(2.52)\end{array}$ & $\begin{array}{c}1.22 \\
(2.48)\end{array}$ \\
\hline \multicolumn{6}{|l|}{ Financial Conditions } \\
\hline $\begin{array}{c}\text { Domestic Credit Private Sector, } \\
\% \text { GDP } 2006\end{array}$ & $\begin{array}{l}-.06 \\
(.05)\end{array}$ & $\begin{array}{l}-.05 \\
(.04) \\
\end{array}$ & $\begin{array}{l}-.05 \\
(.04)\end{array}$ & $\begin{array}{l}-.05 \\
(.03)\end{array}$ & $\begin{array}{l}-.091^{*} \\
(.045)\end{array}$ \\
\hline $\begin{array}{c}\text { Domestic Bank Credit, } \\
\text { \%GDP } 2006\end{array}$ & $\begin{array}{l}-.06 \\
(.04)\end{array}$ & $\begin{array}{l}-.06^{*} \\
(.03)\end{array}$ & $\begin{array}{l}-.02 \\
(.04)\end{array}$ & $\begin{array}{l}-.056^{*} \\
(.025)\end{array}$ & $\begin{array}{l}-.09^{*} \\
(.04)\end{array}$ \\
\hline $\begin{array}{c}\text { Private Sector } \\
\text { Credit Access, } 2006\end{array}$ & $\begin{array}{c}-.34 \\
(1.66)\end{array}$ & $\begin{array}{c}-.15 \\
(1.68)\end{array}$ & $\begin{array}{c}.25 \\
(1.80)\end{array}$ & $\begin{array}{c}-.28 \\
(2.63)\end{array}$ & $\begin{array}{c}.68 \\
(1.51)\end{array}$ \\
\hline $\begin{array}{l}\text { Bank Non-Performing } \\
\text { Loans, \% Loans } 2006\end{array}$ & $\begin{array}{l}-1.00 \\
(.53) \\
\end{array}$ & $\begin{array}{r}-1.04 \\
(.53) \\
\end{array}$ & $\begin{array}{l}-1.00 \\
(.53) \\
\end{array}$ & $\begin{array}{c}-1.10^{*} \\
(.42)\end{array}$ & $\mathrm{n} / \mathrm{a}$ \\
\hline $\begin{array}{c}\text { Bank Liquid Reserves, } \\
\text { \%Assets } 2006\end{array}$ & $\begin{array}{c}.03 \\
(.11)\end{array}$ & $\begin{array}{l}.05 \\
(.06)\end{array}$ & $\begin{array}{l}.01 \\
(.10)\end{array}$ & $\begin{array}{l}.05 \\
(.06)\end{array}$ & $\begin{array}{l}-.06 \\
(.08)\end{array}$ \\
\hline $\begin{array}{l}\text { Bank Capital, } \\
\% \text { Assets } 2006\end{array}$ & $\begin{array}{l}.21 \\
(.69)\end{array}$ & $\begin{array}{c}.24 \\
(.62) \\
\end{array}$ & $\begin{array}{c}.61 \\
(.89) \\
\end{array}$ & $\begin{array}{l}.21 \\
(.60)\end{array}$ & $\begin{array}{l}-.19 \\
(.76) \\
\end{array}$ \\
\hline $\begin{array}{c}\text { Bank Claims, } \\
\text { \%Deposits } 2006\end{array}$ & $\begin{array}{l}-9.1 * \\
(4.3)\end{array}$ & $\begin{array}{l}-6.39^{*} \\
(2.92) \\
\end{array}$ & $\begin{array}{l}-8.53 * \\
(3.94) \\
\end{array}$ & $\begin{array}{l}-6.2 * \\
(2.7) \\
\end{array}$ & $\begin{array}{c}.01 \\
(.01) \\
\end{array}$ \\
\hline \multicolumn{6}{|l|}{ Asset Price Appreciation } \\
\hline $\begin{array}{c}\text { \% Chg Real Estate Prices, } \\
2003-6 \\
\end{array}$ & $\begin{array}{l}-2.96 \\
(5.37) \\
\end{array}$ & $\begin{array}{l}-3.28 \\
(5.41) \\
\end{array}$ & $\begin{array}{l}-11.4 \\
(5.8) \\
\end{array}$ & $\begin{array}{l}-2.96 \\
(5.37) \\
\end{array}$ & $\begin{array}{l}-3.42 \\
(5.34) \\
\end{array}$ \\
\hline $\begin{array}{l}\text { \% Chg Market Cap, } \\
\text { \%GDP 2003-6 }\end{array}$ & $\begin{array}{c}-10.20^{* *} \\
(1.99) \\
\end{array}$ & $\begin{array}{c}-10.5^{* *} \\
(1.90) \\
\end{array}$ & $\begin{array}{c}-10.5^{* *} \\
(2.1) \\
\end{array}$ & $\begin{array}{c}-10.6^{* *} \\
(1.84) \\
\end{array}$ & $\begin{array}{c}-7.2 * * \\
(2.0) \\
\end{array}$ \\
\hline $\begin{array}{l}\text { Stock Market Growth, } \\
2006\end{array}$ & $\begin{array}{l}-.06 \\
(.10)\end{array}$ & $\begin{array}{l}-.11 \\
(.07)\end{array}$ & $\begin{array}{l}-.08 \\
(.13)\end{array}$ & $\begin{array}{l}-.11 \\
(.06)\end{array}$ & $\begin{array}{l}-.03 \\
(.08)\end{array}$ \\
\hline $\begin{array}{l}\text { Market Cap, } \\
\% \text { GDP } 2006\end{array}$ & $\begin{array}{c}.01 \\
(.03) \\
\end{array}$ & $\begin{array}{l}-.00 \\
(.03)\end{array}$ & $\begin{array}{c}.01 \\
(.04) \\
\end{array}$ & $\begin{array}{l}-.00 \\
(.03)\end{array}$ & $\begin{array}{l}-.02 \\
(.03)\end{array}$ \\
\hline $\begin{array}{l}\text { Stocks Traded, } \\
\% \text { GDP2006 }\end{array}$ & $\begin{array}{l}.02 \\
(.03)\end{array}$ & $\begin{array}{l}.02 \\
(.03)\end{array}$ & $\begin{array}{l}.02 \\
(.03)\end{array}$ & $\begin{array}{l}.02 \\
(.03)\end{array}$ & $\begin{array}{l}-.02 \\
(.03)\end{array}$ \\
\hline \multicolumn{6}{|l|}{ International Imbalances } \\
\hline $\begin{array}{c}\text { Net External Position, } \\
\% \text { GDP } 2004\end{array}$ & $\begin{array}{c}4.23 \\
(2.58) \\
\end{array}$ & $\begin{array}{l}5.07^{*} \\
(2.11) \\
\end{array}$ & $\begin{array}{c}3.36 \\
(2.66) \\
\end{array}$ & $\begin{array}{l}5.07^{*} \\
(2.12) \\
\end{array}$ & $\begin{array}{c}2.1 \\
(3.6) \\
\end{array}$ \\
\hline $\begin{array}{l}\text { Current Account, } \\
\text { \%GDP } 2006\end{array}$ & $\begin{array}{l}.56^{* *} \\
(.17)\end{array}$ & $\begin{array}{l}.57^{* *} \\
(.18)\end{array}$ & $\begin{array}{l}.41 * * \\
(.17)\end{array}$ & $\begin{array}{l}.54 * * \\
(.16)\end{array}$ & $\begin{array}{l}-.08 \\
(.16)\end{array}$ \\
\hline $\begin{array}{c}\text { Debt Service, } \\
\% \text { Exports } 2006\end{array}$ & $\begin{array}{l}-.17 \\
(.42) \\
\end{array}$ & $\begin{array}{l}-.17 \\
(.41) \\
\end{array}$ & $\begin{array}{l}-.36 \\
(.38) \\
\end{array}$ & $\begin{array}{l}-.01 \\
(.16) \\
\end{array}$ & $\mathrm{n} / \mathrm{a}$ \\
\hline $\begin{array}{l}\text { External Debt, } \\
\% \text { GNI } 2006\end{array}$ & $\begin{array}{l}-.01 \\
(.18)\end{array}$ & $\begin{array}{l}-.01 \\
(.17)\end{array}$ & $\mathrm{n} / \mathrm{a}$ & $\begin{array}{l}.24 * * \\
(.06)\end{array}$ & $\mathrm{n} / \mathrm{a}$ \\
\hline
\end{tabular}




\begin{tabular}{|c|c|c|c|c|c|}
\hline $\begin{array}{c}\text { Gross Financing via international } \\
\text { capital markets, \% GDP } 2006\end{array}$ & $\begin{array}{c}2.32 * * \\
(.31)\end{array}$ & $\begin{array}{l}.0000 \\
(.0002)\end{array}$ & $\begin{array}{l}-.84 \\
(.63)\end{array}$ & $\begin{array}{c}2.20^{* *} \\
(.31)\end{array}$ & $\mathrm{n} / \mathrm{a}$ \\
\hline $\begin{array}{l}\text { Real Effective Exchange } \\
\text { Rate } 2006(2000=100)\end{array}$ & $\begin{array}{l}-.22 \\
(.13)\end{array}$ & $\begin{array}{l}-.22 \\
(.13)\end{array}$ & $\begin{array}{l}-.23 \\
(.15) \\
\end{array}$ & $\begin{array}{l}-.19 \\
(.10)\end{array}$ & $\mathrm{n} / \mathrm{a}$ \\
\hline $\begin{array}{c}\text { Total Reserves, } \\
\text { \%external debt } 2006\end{array}$ & $\begin{array}{l}-.00 \\
(.01)\end{array}$ & $\begin{array}{c}-.028 * * \\
(.007)\end{array}$ & $\begin{array}{l}.01 \\
(.01)\end{array}$ & $\begin{array}{l}-.002 \\
(.004)\end{array}$ & $\begin{array}{l}-.013^{*} \\
(.005)\end{array}$ \\
\hline $\begin{array}{l}\text { Short-Term Debt, } \\
\text { \%Reserves } 2006\end{array}$ & $\begin{array}{l}.36^{* *} \\
(.08)\end{array}$ & $\begin{array}{l}.00010^{*} \\
(.00002)\end{array}$ & $\begin{array}{l}-.10 \\
(.10)\end{array}$ & $\begin{array}{l}.13^{* *} \\
(.03)\end{array}$ & $\begin{array}{l}.36^{* *} \\
(.04)\end{array}$ \\
\hline $\begin{array}{c}\text { Total Reserves, } \\
\text { import months } 2006\end{array}$ & $\begin{array}{l}.36 \\
(.43) \\
\end{array}$ & $\begin{array}{c}.40 \\
(.33) \\
\end{array}$ & $\begin{array}{c}.14 \\
(.38) \\
\end{array}$ & $\begin{array}{c}.40 \\
(.35) \\
\end{array}$ & $\begin{array}{l}-.15 \\
(.36) \\
\end{array}$ \\
\hline $\begin{array}{c}\text { M2, } \\
\%(\text { total reserves - gold) } 2006\end{array}$ & 0 & $\begin{array}{l}-.000001 \\
(.00003)\end{array}$ & $\begin{array}{l}.26 \\
(.17)\end{array}$ & $\begin{array}{l}-.00001 \\
(.00006)\end{array}$ & $\begin{array}{l}.02 \\
(.14)\end{array}$ \\
\hline $\begin{array}{l}\text { M2, \%(Central Bank } \\
\text { foreign assets) } 2006\end{array}$ & $\begin{array}{c}1.7 \mathrm{e}-7 \\
(1.6 \mathrm{e}-6)\end{array}$ & 0 & $\begin{array}{l}.09 \\
(.05)\end{array}$ & 0 & $\begin{array}{l}.-02 \\
(.05)\end{array}$ \\
\hline \multicolumn{6}{|l|}{ Macroeconomic Policies } \\
\hline $\begin{array}{c}\text { Currency Union } \\
\text { member, } 2006\end{array}$ & $\begin{array}{c}9.1 \\
(5.1) \\
\end{array}$ & $\begin{array}{l}11.9^{*} \\
(4.4)\end{array}$ & $\begin{array}{c}5.15 \\
(4.97) \\
\end{array}$ & $\begin{array}{l}12.2^{* *} \\
(4.23)\end{array}$ & $\begin{array}{l}-.01 \\
(.01) \\
\end{array}$ \\
\hline $\begin{array}{l}\text { GDP of Monetary } \\
\text { Zone, } 2006 \\
\end{array}$ & $\begin{array}{l}-2.9 \mathrm{e}-13 \\
(2.7 \mathrm{e}-13) \\
\end{array}$ & $\begin{array}{l}-3.0 \mathrm{e}-13 \\
(2.0 \mathrm{e}-13) \\
\end{array}$ & 0 & $\begin{array}{c}2.9 \mathrm{e}-13 \\
(2.7 \mathrm{e}-13) \\
\end{array}$ & $\begin{array}{l}-2.2 \mathrm{e}-13 \\
(1.6 \mathrm{e}-13) \\
\end{array}$ \\
\hline $\begin{array}{l}\text { EU but non-EMU } \\
\text { Member, } 2006\end{array}$ & $\begin{array}{l}-10.8 \\
(5.8) \\
\end{array}$ & $\begin{array}{c}-11.4^{*} \\
(5.1) \\
\end{array}$ & $\begin{array}{c}-14.2^{* *} \\
(5.1)\end{array}$ & $\begin{array}{c}-10.6^{*} \\
(5.4)\end{array}$ & $\begin{array}{c}-10.6^{*} \\
(5.3)\end{array}$ \\
\hline $\begin{array}{c}\text { Inflation Targeter, } \\
2006 \\
\end{array}$ & $\begin{array}{c}.02 \\
(.02) \\
\end{array}$ & $\begin{array}{l}.02 \\
(.03) \\
\end{array}$ & $\begin{array}{c}.57 \\
(4.9) \\
\end{array}$ & $\begin{array}{c}.02 \\
(.02) \\
\end{array}$ & $\begin{array}{l}-5.9 \\
(8.6) \\
\end{array}$ \\
\hline $\begin{array}{c}\text { M2, } \\
\text { \%GDP } 2006\end{array}$ & $\begin{array}{l}-9.8 \mathrm{e}-7 \\
(6.3 \mathrm{e}-6)\end{array}$ & $\mathrm{n} / \mathrm{a}$ & $\begin{array}{l}-.00 \\
(.05)\end{array}$ & $\begin{array}{l}-.00002 \\
(.00002)\end{array}$ & $\begin{array}{l}-.04 \\
(.06)\end{array}$ \\
\hline $\begin{array}{c}\text { M3, } \\
\text { \%GDP } 2006\end{array}$ & $\begin{array}{l}-8.3 \mathrm{e}-7 \\
(4.7 \mathrm{e}-6)\end{array}$ & $\begin{array}{l}-1.1 \mathrm{e}-6 \\
(6.1 \mathrm{e}-6)\end{array}$ & $\begin{array}{l}-.01 \\
(.05)\end{array}$ & $\begin{array}{l}-.00001 \\
(.00004)\end{array}$ & $\mathrm{n} / \mathrm{a}$ \\
\hline $\begin{array}{c}\text { Gov’t Budget } \\
\text { Surplus/Deficit, \% GDP } 2006\end{array}$ & $\begin{array}{l}.22 \\
(.52)\end{array}$ & $\begin{array}{l}.23 \\
(.52)\end{array}$ & $\begin{array}{l}.12 \\
(.52)\end{array}$ & $\begin{array}{l}.65^{*} \\
(.31)\end{array}$ & $\begin{array}{l}-.34 \\
(.49)\end{array}$ \\
\hline $\begin{array}{l}\text { Central Gov`t Debt, } \\
\text { \%GDP } 2006\end{array}$ & $\begin{array}{l}-.01 \\
(.07)\end{array}$ & $\begin{array}{l}-.01 \\
(.08)\end{array}$ & $\begin{array}{l}-.03 \\
(.08)\end{array}$ & $\begin{array}{l}-.02 \\
(.07)\end{array}$ & $\begin{array}{l}-.00 \\
(.09)\end{array}$ \\
\hline $\begin{array}{c}\text { Debt, } \\
\text { \%GNP } 2006\end{array}$ & $\begin{array}{l}.09 \\
(.20)\end{array}$ & $\begin{array}{l}.08 \\
(.20)\end{array}$ & $\begin{array}{c}-.35^{* *} \\
(.13)\end{array}$ & $\begin{array}{l}.22 * * \\
(.06)\end{array}$ & $\mathrm{n} / \mathrm{a}$ \\
\hline $\begin{array}{l}\text { Debt Service, } \\
\% \text { GDP } 2006\end{array}$ & $\begin{array}{c}-1.81^{*} \\
(.71)\end{array}$ & $\begin{array}{c}-1.76^{*} \\
(.70)\end{array}$ & $\begin{array}{l}-.97 \\
(.56)\end{array}$ & $\begin{array}{c}-2.61^{* *} \\
(.29)\end{array}$ & $\mathrm{n} / \mathrm{a}$ \\
\hline $\begin{array}{l}\text { CPI Inflation, } \\
2006 \\
\end{array}$ & $\begin{array}{l}.32 \\
(.72) \\
\end{array}$ & $\begin{array}{l}.36 \\
(.72) \\
\end{array}$ & $\begin{array}{l}.11 \\
(.69) \\
\end{array}$ & $\begin{array}{l}-.18 \\
(.65) \\
\end{array}$ & $\begin{array}{c}.46 \\
(.70) \\
\end{array}$ \\
\hline $\begin{array}{l}\text { GDP Growth, } \\
2006\end{array}$ & $\begin{array}{l}-.15 \\
(.74) \\
\end{array}$ & $\begin{array}{l}-.10 \\
(.74) \\
\end{array}$ & $\begin{array}{l}-1.25 \\
(.81) \\
\end{array}$ & $\begin{array}{l}-.72 \\
(.61)\end{array}$ & $\begin{array}{l}-.29 \\
(.81) \\
\end{array}$ \\
\hline \multicolumn{6}{|l|}{ Institutions } \\
\hline $\begin{array}{l}\text { Credit/Labor/Business } \\
\text { Regulation, EFW } 2006 \\
\end{array}$ & $\begin{array}{c}2.14 \\
(2.73) \\
\end{array}$ & $\begin{array}{c}2.39 \\
(2.75) \\
\end{array}$ & $\begin{array}{c}3.41 \\
(2.82) \\
\end{array}$ & $\begin{array}{c}1.04 \\
(2.33) \\
\end{array}$ & $\begin{array}{c}3.52 \\
(2.20) \\
\end{array}$ \\
\hline $\begin{array}{c}\text { Polity, } \\
2006 \\
\end{array}$ & $\begin{array}{l}-.25 \\
(.33) \\
\end{array}$ & $\begin{array}{l}.36 \\
(.24) \\
\end{array}$ & $\begin{array}{l}.35 \\
(.26) \\
\end{array}$ & $\begin{array}{l}-.34 \\
(.23) \\
\end{array}$ & $\begin{array}{l}.39 \\
(.39) \\
\end{array}$ \\
\hline $\begin{array}{c}\text { Constraints on } \\
\text { Executive, } 2006\end{array}$ & $\begin{array}{l}-1.58 \\
(1.12)\end{array}$ & $\begin{array}{l}-1.57 \\
(1.12)\end{array}$ & $\begin{array}{c}1.58 \\
(1.12)\end{array}$ & $\begin{array}{l}-1.49 \\
(.89)\end{array}$ & $\begin{array}{l}-1.75 \\
(1.29)\end{array}$ \\
\hline $\begin{array}{l}\text { Overall Economic } \\
\text { Freedom, } 2006\end{array}$ & $\begin{array}{c}2.64 \\
(1.53)\end{array}$ & $\begin{array}{c}3.34 \\
(3.61)\end{array}$ & $\begin{array}{c}3.90 \\
(3.77)\end{array}$ & $\begin{array}{c}1.75 \\
(2.92)\end{array}$ & $\begin{array}{c}2.78 \\
(3.09)\end{array}$ \\
\hline $\begin{array}{l}\text { Common Law } \\
\text { Country }\end{array}$ & $\begin{array}{c}2.98 \\
(4.79)\end{array}$ & $\begin{array}{c}5.57 \\
(10.31)\end{array}$ & $\begin{array}{c}8.49 \\
(4.72)\end{array}$ & $\begin{array}{c}3.21 \\
(8.17)\end{array}$ & $\begin{array}{l}.002 \\
(.004)\end{array}$ \\
\hline $\begin{array}{l}\text { Control of } \\
\text { Corruption }\end{array}$ & $\begin{array}{c}.56 \\
(3.34)\end{array}$ & $\begin{array}{c}.44 \\
(4.40)\end{array}$ & $\begin{array}{c}6.20 \\
(3.47)\end{array}$ & $\begin{array}{c}-.35 \\
(4.48)\end{array}$ & $\begin{array}{l}-3.8 \\
(4.8)\end{array}$ \\
\hline $\begin{array}{l}\text { Regulatory } \\
\text { Quality }\end{array}$ & $\begin{array}{c}.88 \\
(3.53)\end{array}$ & $\begin{array}{c}1.09 \\
(4.98)\end{array}$ & $\begin{array}{c}.21 \\
(3.7)\end{array}$ & $\begin{array}{c}1.27 \\
(4.72)\end{array}$ & $\begin{array}{l}-.97 \\
(3.4)\end{array}$ \\
\hline $\begin{array}{c}\text { Rule of } \\
\text { Law }\end{array}$ & $\begin{array}{c}-.51 \\
(3.80)\end{array}$ & $\begin{array}{c}-.68 \\
(3.80)\end{array}$ & $\begin{array}{c}2,77 \\
(3.98)\end{array}$ & $\begin{array}{c}-.11 \\
(4.30)\end{array}$ & $\begin{array}{l}-3.40 \\
(3.36)\end{array}$ \\
\hline $\begin{array}{c}\text { Political } \\
\text { Rights, } 2006 \\
\end{array}$ & $\begin{array}{c}1.22 \\
(1.12)\end{array}$ & $\begin{array}{c}1.24 \\
(1.12)\end{array}$ & $\begin{array}{c}.92 \\
(1.15) \\
\end{array}$ & $\begin{array}{l}1.58 \\
(.93) \\
\end{array}$ & $\begin{array}{c}1.36 \\
(1.26) \\
\end{array}$ \\
\hline $\begin{array}{c}\text { Civil } \\
\text { Liberties, } 2006\end{array}$ & $\begin{array}{c}1.36 \\
(1.35)\end{array}$ & $\begin{array}{c}1.40 \\
(1.35)\end{array}$ & $\begin{array}{c}.88 \\
(1.38)\end{array}$ & $\begin{array}{c}1.47 \\
(1.08)\end{array}$ & $\begin{array}{c}1.08 \\
(1.49)\end{array}$ \\
\hline
\end{tabular}




\begin{tabular}{|c|c|c|c|c|c|}
\hline $\begin{array}{c}\text { Government Size, } \\
2006\end{array}$ & $\begin{array}{c}2.64 \\
(1.53)\end{array}$ & $\begin{array}{c}2.85 \\
(1.53)\end{array}$ & $\begin{array}{l}3.26^{*} \\
(1.59)\end{array}$ & $\begin{array}{c}2.69 \\
(1.64)\end{array}$ & $\begin{array}{c}1.68 \\
(1.41)\end{array}$ \\
\hline $\begin{array}{c}\text { Legal Security of Property } \\
\text { Rights, } 2006\end{array}$ & $\begin{array}{c}.03 \\
(2.24)\end{array}$ & $\begin{array}{c}.21 \\
(2.26)\end{array}$ & $\begin{array}{c}1.33 \\
(2.33)\end{array}$ & $\begin{array}{c}-.04 \\
(1.57)\end{array}$ & $\begin{array}{l}-.15 \\
(2.07)\end{array}$ \\
\hline $\begin{array}{l}\text { Sound Money } \\
\text { Access, } 2006\end{array}$ & $\begin{array}{c}-.24 \\
(2.02) \\
\end{array}$ & $\begin{array}{l}-.20 \\
(2.05) \\
\end{array}$ & $\begin{array}{c}-.78 \\
(2.18) \\
\end{array}$ & $\begin{array}{l}.56 \\
(1.71) \\
\end{array}$ & $\begin{array}{c}.80 \\
(2.00) \\
\end{array}$ \\
\hline \multicolumn{6}{|l|}{ Geography } \\
\hline $\begin{array}{l}\text { Log of } \\
\text { Latitude }\end{array}$ & $\begin{array}{l}-4.8 \\
(2.5) \\
\end{array}$ & $\begin{array}{l}-5.67^{*} \\
(1.95) \\
\end{array}$ & $\begin{array}{c}-7.54 * * \\
(2.70) \\
\end{array}$ & $\begin{array}{c}-5.7 * * \\
(1.9) \\
\end{array}$ & $\begin{array}{l}-.56 \\
(2.45) \\
\end{array}$ \\
\hline $\begin{array}{c}\text { East } \\
\text { Asian }\end{array}$ & $\begin{array}{c}3.9 \\
(6.8) \\
\end{array}$ & $\begin{array}{l}.75 \\
(7.9) \\
\end{array}$ & $\begin{array}{c}-3.6 \\
(6.65) \\
\end{array}$ & $\begin{array}{l}-.004 \\
(.003)\end{array}$ & $\mathrm{n} / \mathrm{a}$ \\
\hline $\begin{array}{c}\text { Central/Eastern European } \\
\text { or Central Asian }\end{array}$ & $\begin{array}{c}-16.7^{* * *} \\
(5.2)\end{array}$ & $\begin{array}{c}-16.9^{* *} \\
(5.4)\end{array}$ & $\begin{array}{c}-22.0 * * \\
(4.73)\end{array}$ & $\begin{array}{c}-16.2^{* * *} \\
(5.3)\end{array}$ & $\mathrm{n} / \mathrm{a}$ \\
\hline $\begin{array}{l}\text { Commodity } \\
\text { Exporter }\end{array}$ & $\begin{array}{c}1.5 \\
(4.7)\end{array}$ & $\begin{array}{c}.73 \\
(4.55)\end{array}$ & $\begin{array}{c}5.58 \\
(4.37)\end{array}$ & $\begin{array}{l}-1.9 \\
(4.8)\end{array}$ & $\begin{array}{c}1.67 \\
(4.11)\end{array}$ \\
\hline $\begin{array}{c}\text { English } \\
\text { Language }\end{array}$ & $\begin{array}{c}6.23 \\
(4.71)\end{array}$ & $\begin{array}{c}6.33 \\
(4.70)\end{array}$ & $\begin{array}{c}12.8^{* *} \\
(4.3)\end{array}$ & $\begin{array}{c}8.46 \\
(6.76)\end{array}$ & $\begin{array}{c}4.37 \\
(4.61)\end{array}$ \\
\hline
\end{tabular}

Coefficients, with standard error displayed in parentheses. Coefficients significantly different from zero at .05 (.01) significance level marked by one (two) asterisk(s).

Each cell represents MIMC estimation on cross-section. Default: 4 consequences (2008 change in Stocks, 2008 Growth, 1-year change in Institutional rating, 2008 Exchange Rate change), fixed loading on stocks. Two control causes (log 2006 population and $\log 2006$ real GDP p/c) included in all runs but not recorded. Adaptive quadrature estimation. 
Table 6: Adding Causes to the MIMIC Model Simultaneously

\begin{tabular}{|c|c|c|c|c|c|}
\hline Extra Cause & Default & $\begin{array}{l}\text { Without } \\
\text { ST Debt }\end{array}$ & $\begin{array}{c}\text { Drop Poor } \\
\text { (GDPpc }<\$ 5 k)\end{array}$ & $\begin{array}{l}\text { Drop Small } \\
(\text { Pop }<1 \mathrm{~m})\end{array}$ & $\begin{array}{c}\text { Drop Size, } \\
\text { Income }\end{array}$ \\
\hline \multicolumn{6}{|l|}{ Financial Policies } \\
\hline $\begin{array}{c}\text { Overall Capital } \\
\text { Stringency, } 2003\end{array}$ & $\begin{array}{c}1.8 \\
(1.9) \\
\end{array}$ & $\begin{array}{c}1.1 \\
(1.2)\end{array}$ & $\begin{array}{c}.1 \\
(1.8)\end{array}$ & $\begin{array}{c}1.8 \\
(1.9)\end{array}$ & $\begin{array}{c}.6 \\
(2.0) \\
\end{array}$ \\
\hline \multicolumn{6}{|l|}{ Financial Conditions } \\
\hline $\begin{array}{c}\text { Domestic Bank Credit, } \\
\% \text { GDP } 2006 \\
\end{array}$ & $\begin{array}{c}.04 \\
(.07) \\
\end{array}$ & $\begin{array}{c}.00 \\
(.04) \\
\end{array}$ & $\begin{array}{c}.01 \\
(.06) \\
\end{array}$ & $\begin{array}{c}.04 \\
(.07) \\
\end{array}$ & $\begin{array}{l}-.04 \\
(.07) \\
\end{array}$ \\
\hline $\begin{array}{c}\text { Bank Claims/Deposits, } \\
2006 \\
\end{array}$ & $\begin{array}{c}9.4 \\
(8.9) \\
\end{array}$ & $\begin{array}{c}1.7 \\
(4.4) \\
\end{array}$ & $\begin{array}{l}10.8 \\
(7.6) \\
\end{array}$ & $\begin{array}{r}10.8 \\
(8.9) \\
\end{array}$ & $\begin{array}{c}8.9 \\
(9.8) \\
\end{array}$ \\
\hline \multicolumn{6}{|l|}{ Asset Price Appreciation } \\
\hline $\begin{array}{l}\text { \% Chg Market Cap, } \\
\text { \%GDP 2003-6 }\end{array}$ & $\begin{array}{l}-5.6^{*} \\
(2.4)\end{array}$ & $\begin{array}{l}-6.6 * * \\
(2.0) \\
\end{array}$ & $\begin{array}{l}-2.3 \\
(2.3)\end{array}$ & $\begin{array}{l}-5.6 \\
(2.4)\end{array}$ & $\begin{array}{l}-6.0 * \\
(2.6)\end{array}$ \\
\hline \multicolumn{6}{|l|}{ International Imbalances } \\
\hline $\begin{array}{c}\text { Current Account, } \\
\text { \%GDP } 2006 \\
\end{array}$ & $\begin{array}{c}.43 \\
(.64) \\
\end{array}$ & $\begin{array}{c}.01 \\
(.24) \\
\end{array}$ & $\begin{array}{c}.04 \\
(.57) \\
\end{array}$ & $\begin{array}{c}.46 \\
(.64) \\
\end{array}$ & $\begin{array}{l}-.64 \\
(.52) \\
\end{array}$ \\
\hline $\begin{array}{l}\text { Short-Term Debt, } \\
\% / \text { Reserves } 2006\end{array}$ & $\begin{array}{l}-.08 \\
(.10)\end{array}$ & & $\begin{array}{l}-.07 \\
(.08)\end{array}$ & $\begin{array}{l}-.09 \\
(.10)\end{array}$ & $\begin{array}{l}-.14 \\
(.10)\end{array}$ \\
\hline \multicolumn{6}{|l|}{ Macroeconomic Policies } \\
\hline $\begin{array}{l}\text { Currency Union member, } \\
2006 \\
\end{array}$ & $\begin{array}{l}10.9 \\
(9.3) \\
\end{array}$ & $\begin{array}{l}-2.8 \\
(4.9) \\
\end{array}$ & $\begin{array}{r}18.5 \\
(9.2) \\
\end{array}$ & $\begin{array}{r}12.3 \\
(9.2) \\
\end{array}$ & $\begin{array}{r}17.4 \\
(9.8) \\
\end{array}$ \\
\hline $\begin{array}{l}\text { EU but non-EMU member, } \\
2006\end{array}$ & $\begin{array}{c}1.0 \\
(10.4)\end{array}$ & $\begin{array}{l}-9.3 \\
(6.4)\end{array}$ & $\begin{array}{c}1.1 \\
(9.7)\end{array}$ & $\begin{array}{c}1.1 \\
(10.4) \\
\end{array}$ & $\begin{array}{c}-9.6 \\
(10.3) \\
\end{array}$ \\
\hline \multicolumn{6}{|l|}{ Institutions } \\
\hline $\begin{array}{c}\text { Polity, } \\
2006\end{array}$ & $\begin{array}{c}.19 \\
(.56)\end{array}$ & $\begin{array}{l}-.22 \\
(.43)\end{array}$ & $\begin{array}{c}.04 \\
(.54)\end{array}$ & $\begin{array}{c}.21 \\
(.56)\end{array}$ & $\begin{array}{l}-.28 \\
(.57)\end{array}$ \\
\hline \multicolumn{6}{|l|}{ Geography } \\
\hline $\begin{array}{c}\text { Log of } \\
\text { Latitude }\end{array}$ & $\begin{array}{c}3.6 \\
(4.4) \\
\end{array}$ & $\begin{array}{c}1.0 \\
(2.7) \\
\end{array}$ & $\begin{array}{c}2.8 \\
(4.1) \\
\end{array}$ & $\begin{array}{c}4.4 \\
(4.4) \\
\end{array}$ & $\begin{array}{c}3.9 \\
(4.7) \\
\end{array}$ \\
\hline $\begin{array}{c}\text { Central/Eastern European } \\
\text { or Central Asian } \\
\end{array}$ & $\begin{array}{l}-19.8 \\
(10.8) \\
\end{array}$ & $\begin{array}{c}-15.4^{*} \\
(6.9) \\
\end{array}$ & $\begin{array}{c}-37.0 * * \\
(10.1) \\
\end{array}$ & $\begin{array}{l}-20.3 \\
(10.8) \\
\end{array}$ & $\begin{array}{l}-26.0^{*} \\
(11.6) \\
\end{array}$ \\
\hline Observations & 40 & 68 & 32 & 39 & 39 \\
\hline
\end{tabular}

Coefficients, with standard error displayed in parentheses. Coefficients significantly different from zero at .05 (.01) significance level marked by one (two) asterisk(s). Each column represents MIMC estimation on cross-section. 4 consequences (2008 change in Stocks, 2008 Growth, 1-year change in Institutional rating, 2008 Exchange Rate change), fixed loading on stocks. Two control causes (log 2006 population and $\log 2006$ real GDP p/c) included but not recorded except where noted. Adaptive quadrature estimation. 
Figure 1

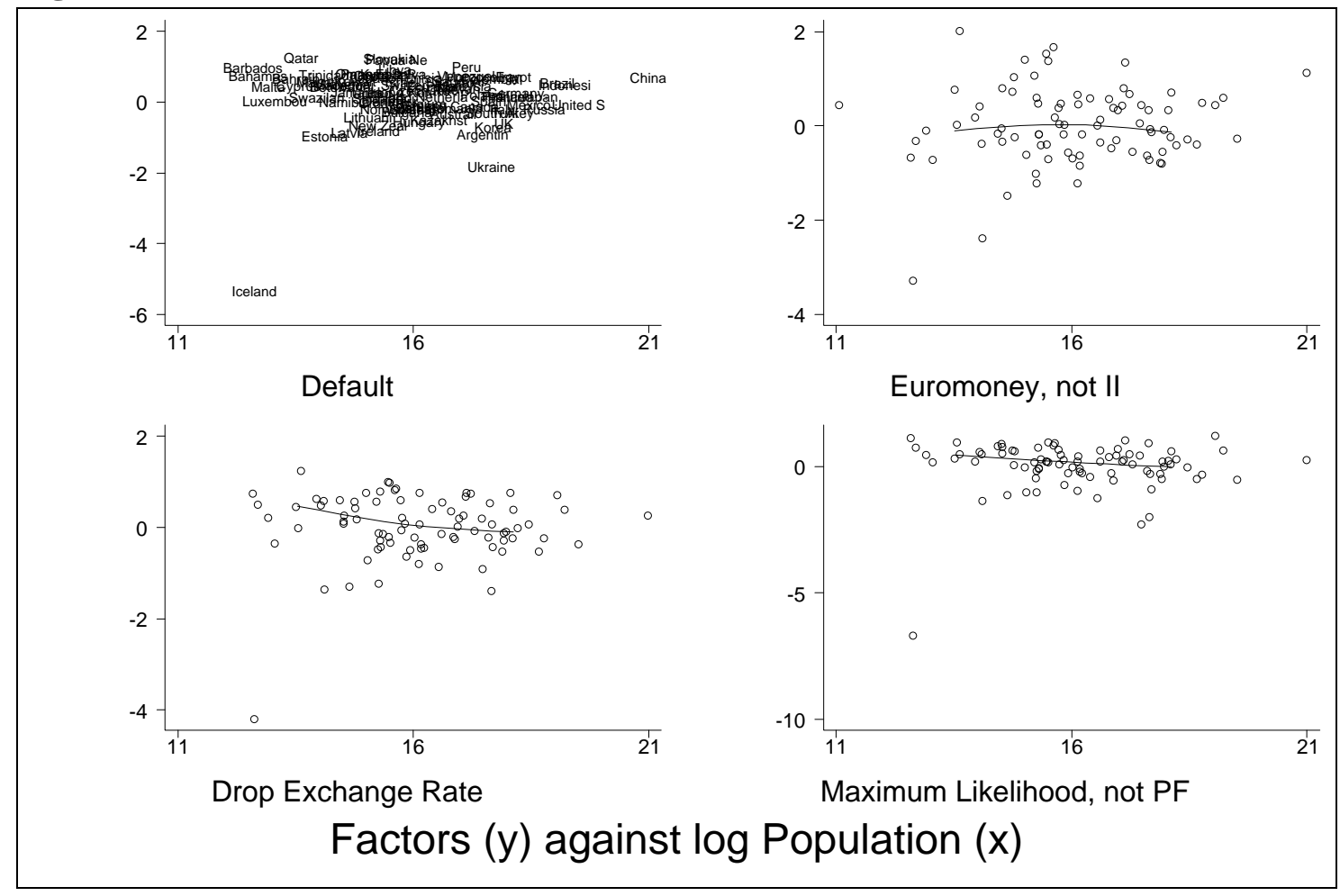

Figure 2
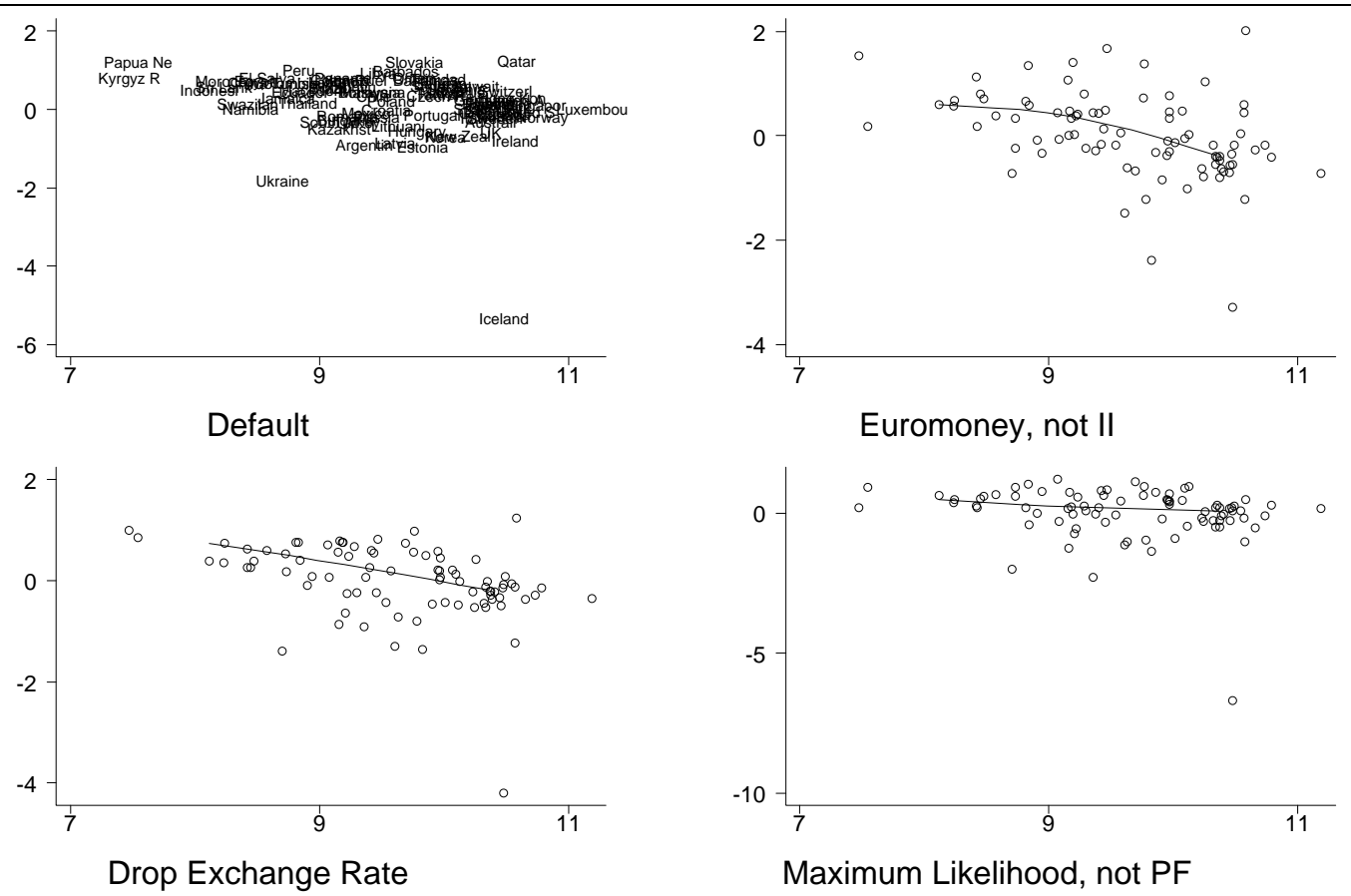

Factors (y) against log real GDP per capita ( $\mathrm{x}$ ) 
Figure 3a

2008 Crisis Manifestations against Capital Regulatory Index
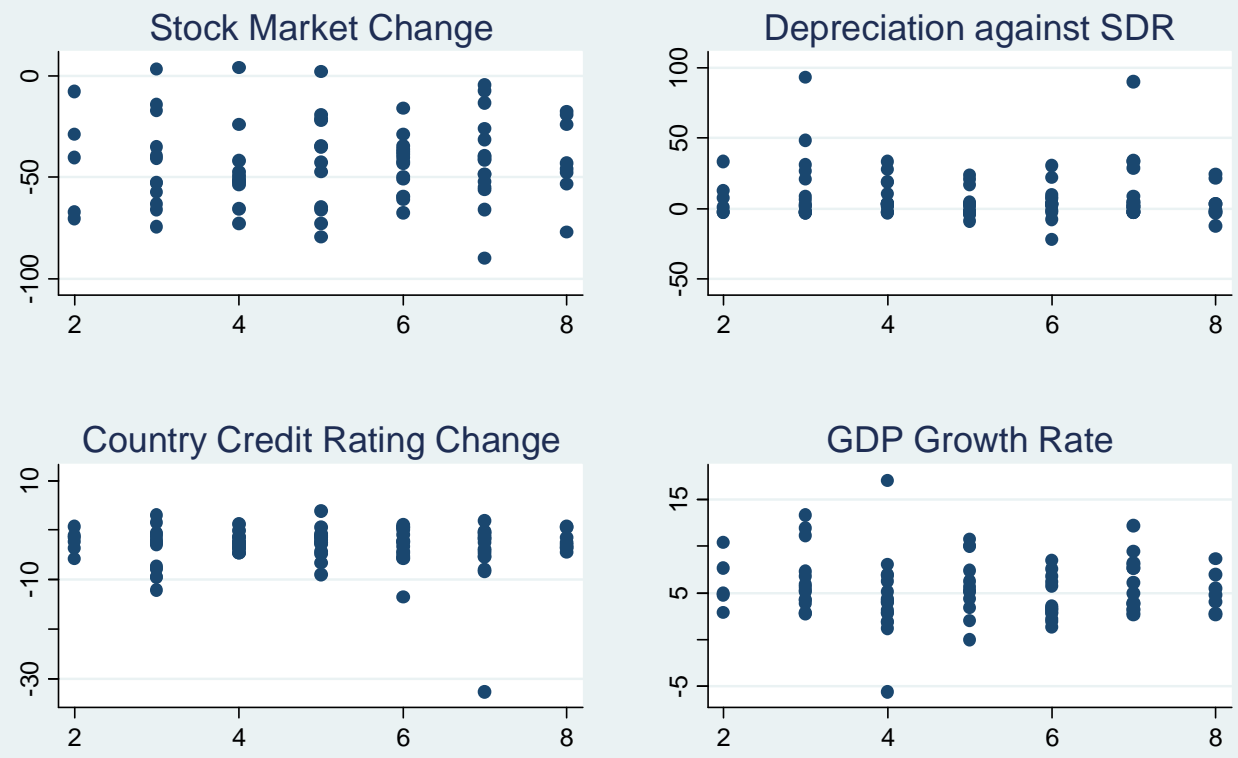

Barth, Caprio and Levine 2003 Capital Regulatory Index

Figure 3b

2008 Crisis Manifestations against Stock Market Runup

Stock Market Change

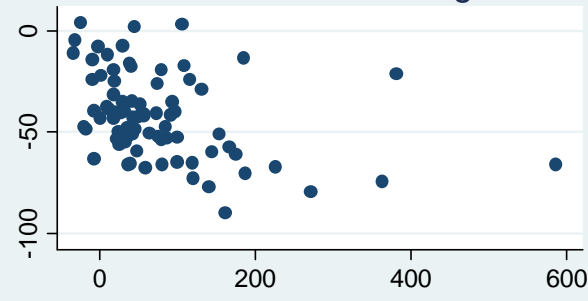

Depreciation against SDR

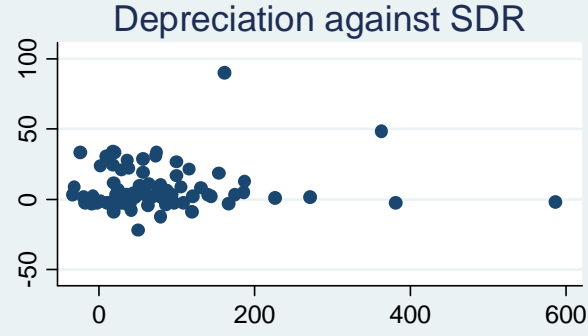

Country Credit Rating Change

GDP Growth Rate
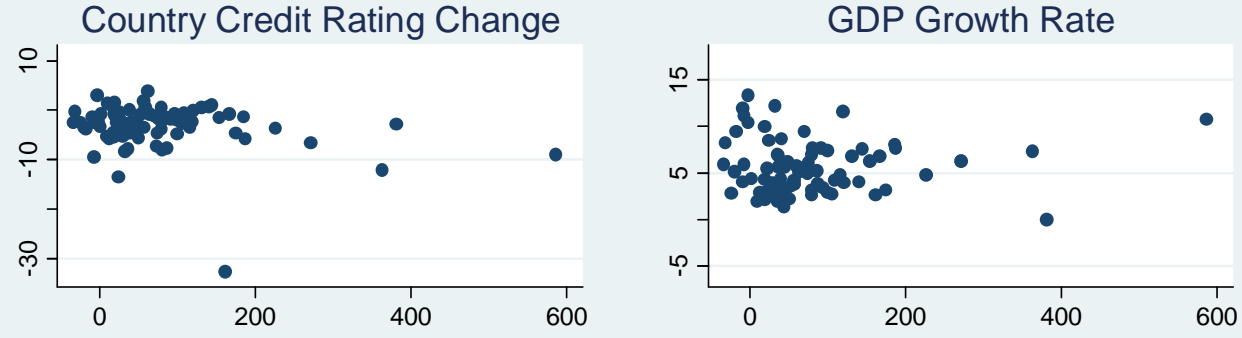

2003-06 Change in Market Capital (\%GDP), WDI 
Figure 3c

2008 Crisis Manifestations against Domestic Credit Growth
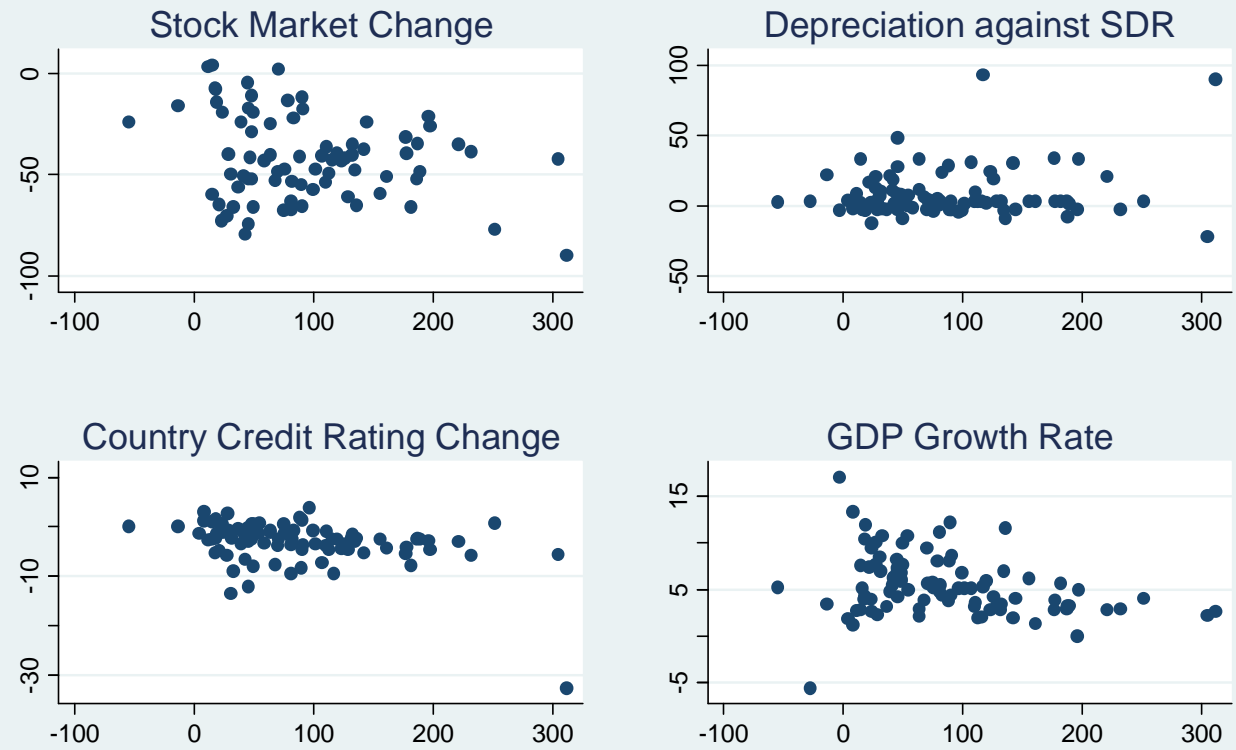

2006 Domestic Bank Credit (\%GDP), WDI

Figure 3d

2008 Crisis Manifestations against Bank Claim/Deposit Ratio
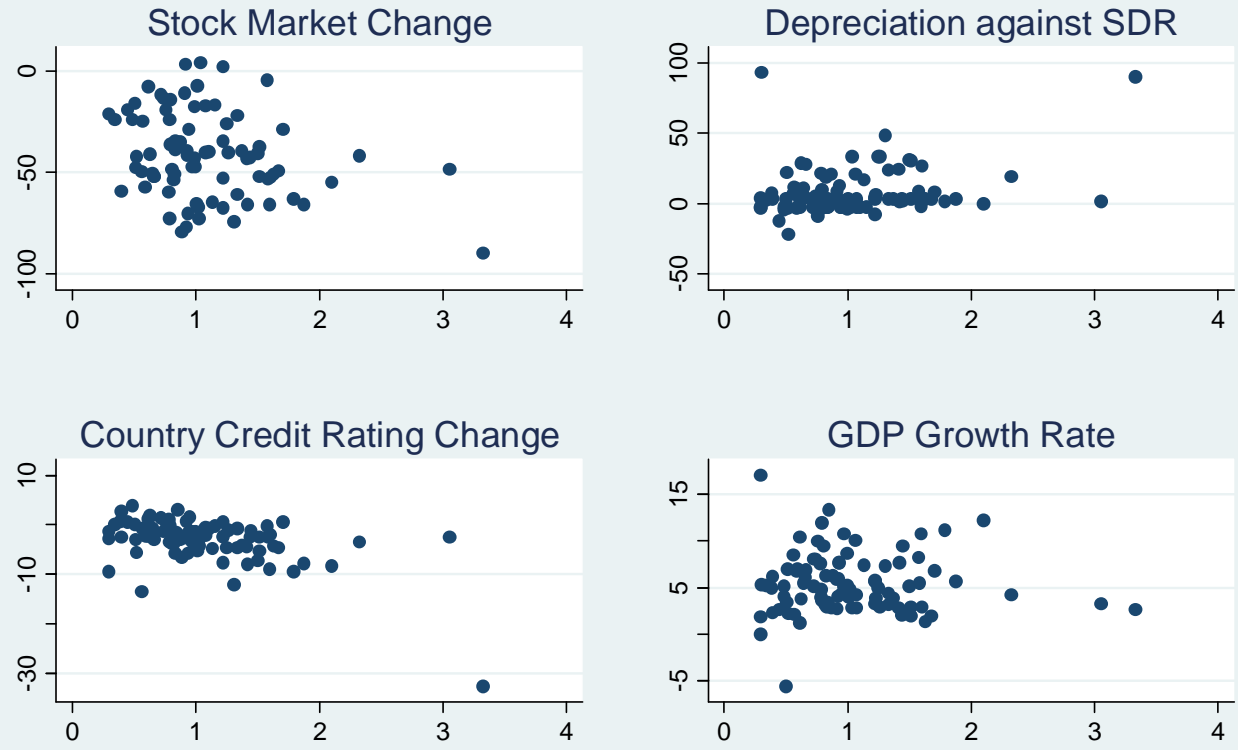

2006 Bank Claims (\%Deposits), IFS 
Figure 3e

2008 Crisis Manifestations against Real Estate Price Runup Stock Market Change
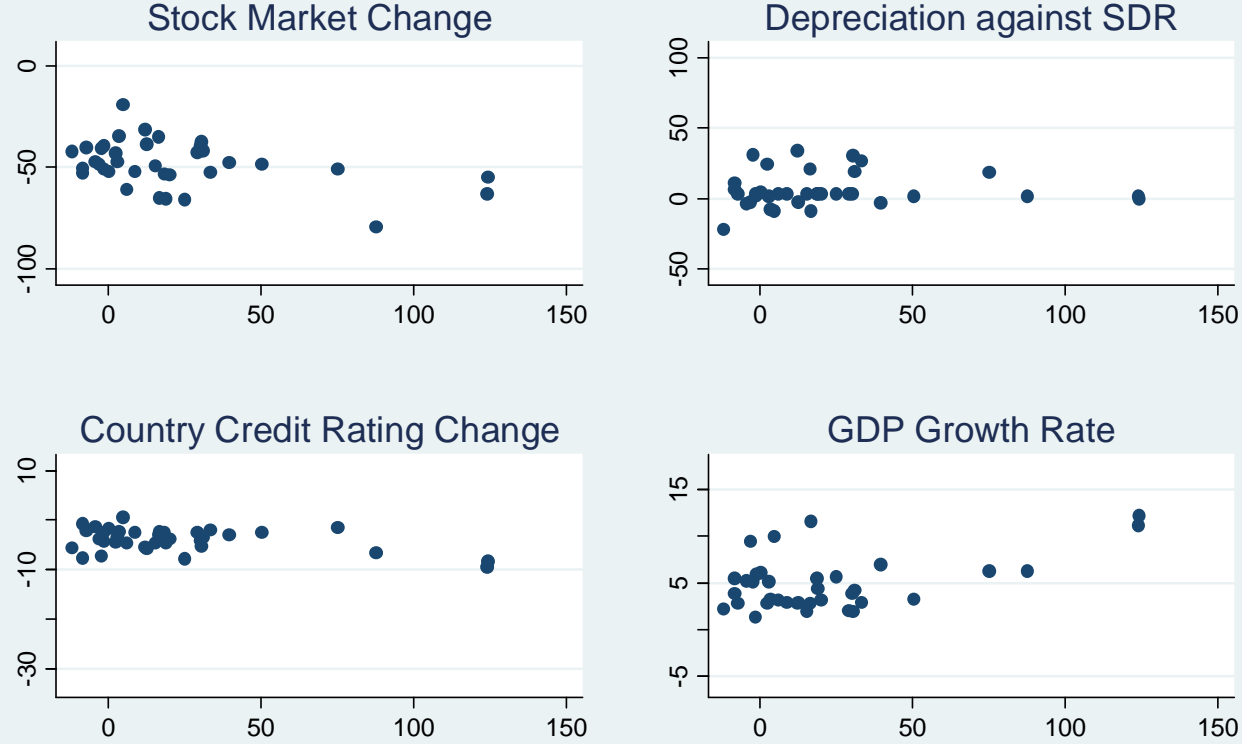

2003-06 Change in Real Real Estate Prices

Figure 3f

2008 Crisis Manifestations against Bank Capital Adequacy Stock Market Change

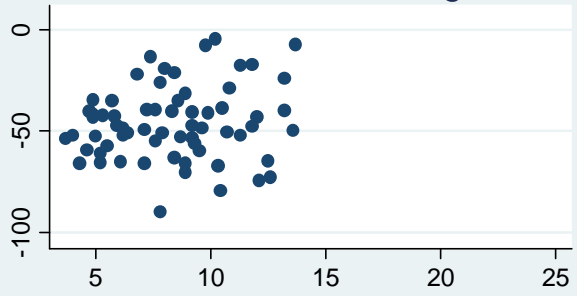

Depreciation against SDR

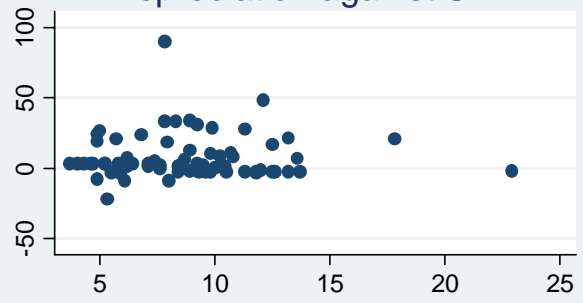

Country Credit Rating Change

GDP Growth Rate
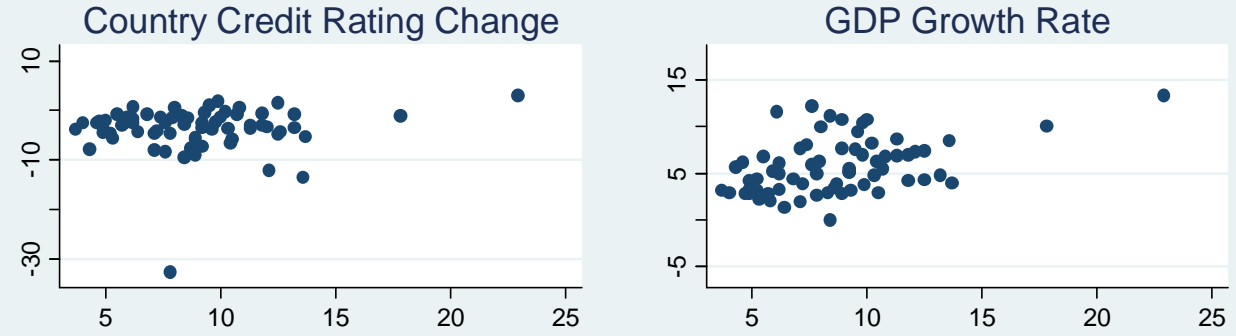

2006 Bank Capital (\%Assets), WDI 
Figure 3g

2008 Crisis Manifestations against Current Account
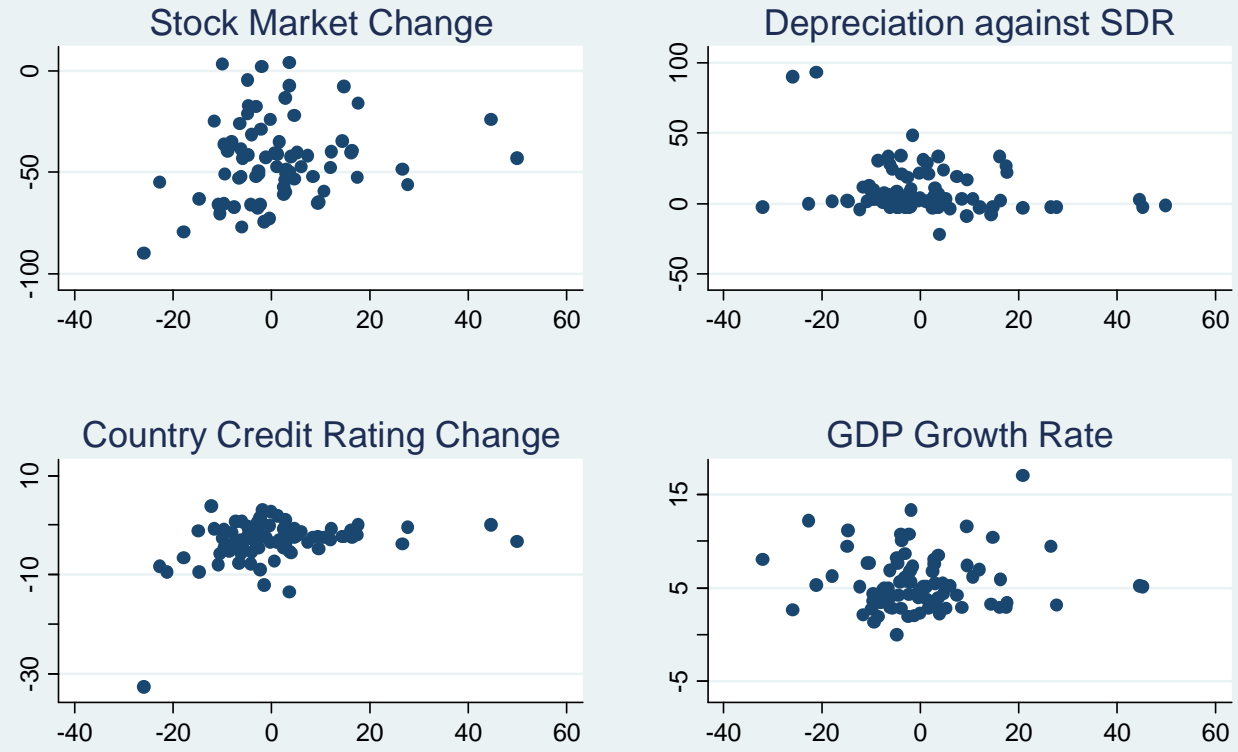

2006 Current Account (\%GDP), WDI

Figure 3h

2008 Crisis Manifestations against Government Budget

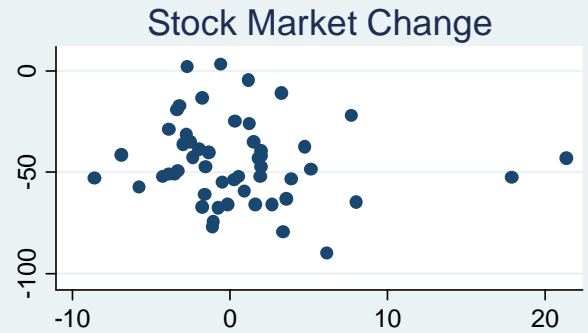

Depreciation against SDR
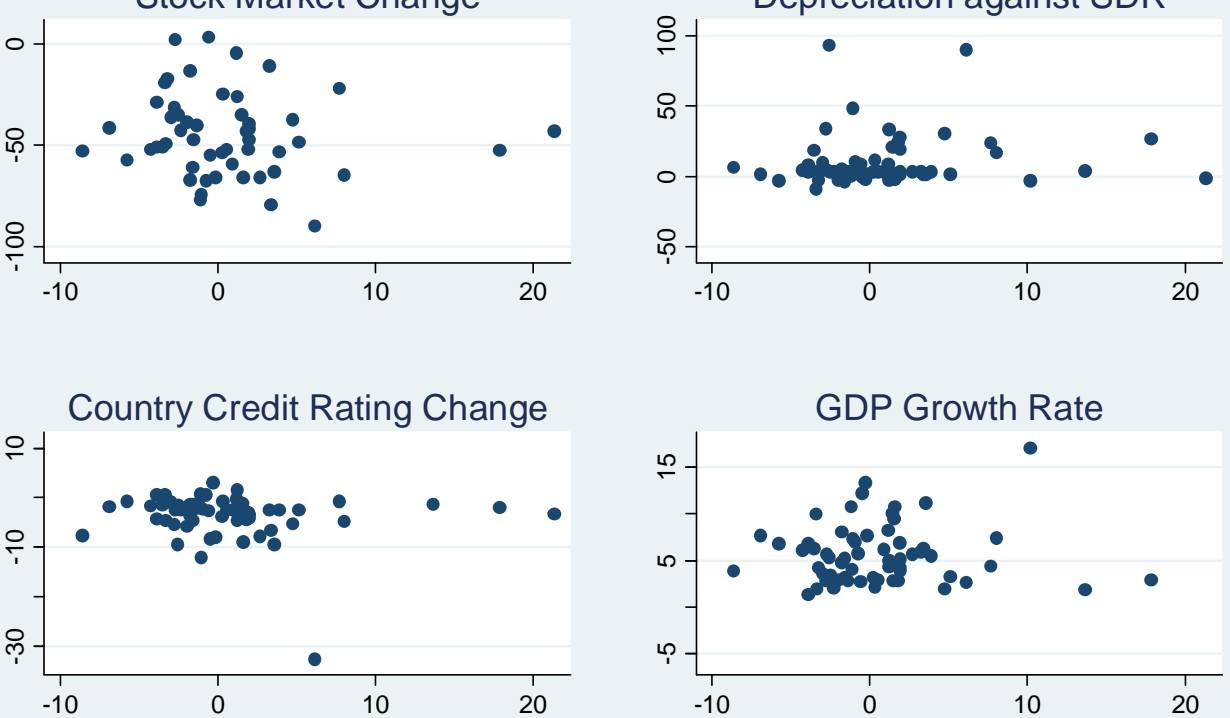

2006 Budget Surplus/Deficit (\%GDP), WDI 


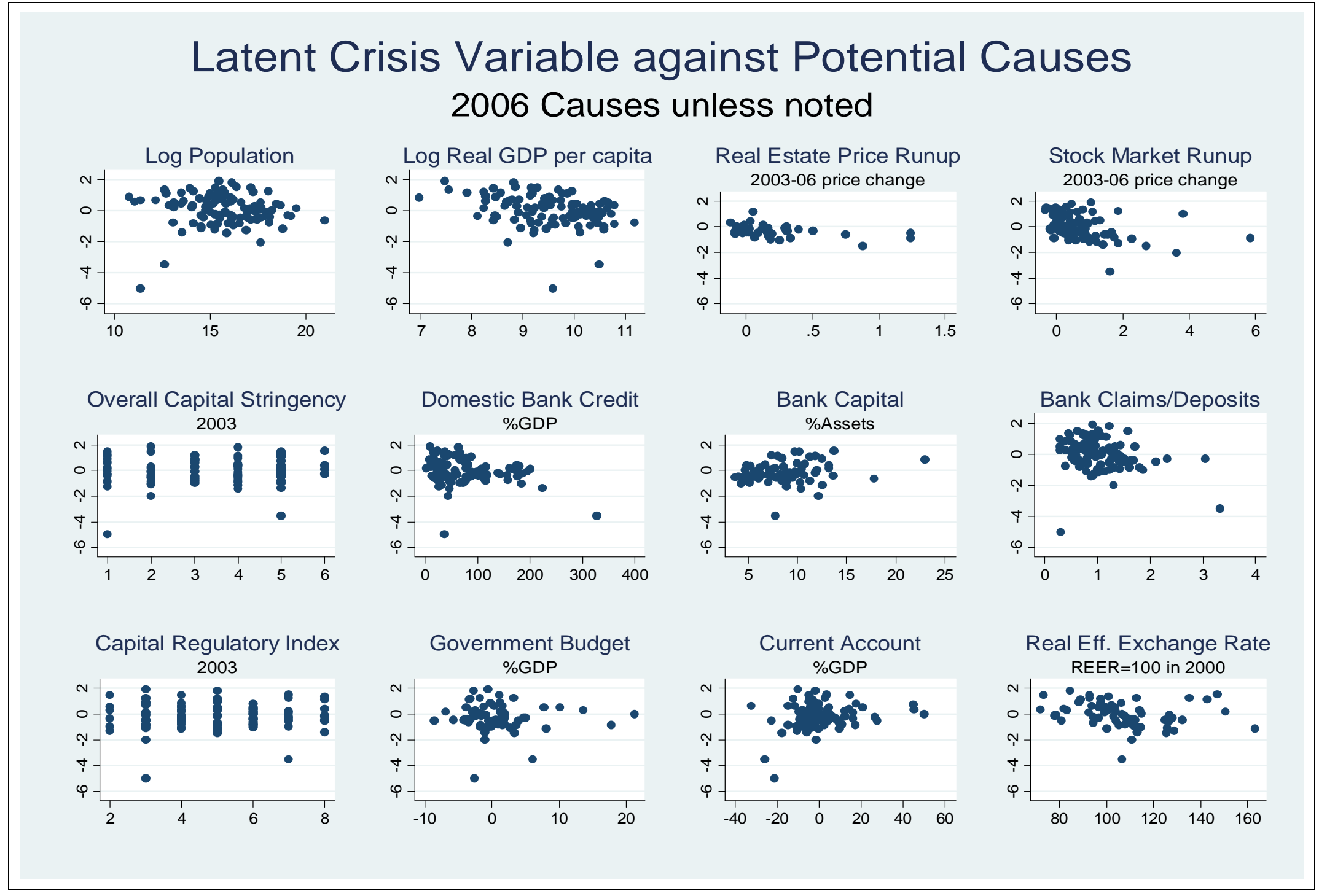




\section{References}

Acemoglu, Daron, Simon Johnson, James Robinson, and Yunyong Thaicharoen, (2003), "Institutional Causes, Macroeconomic Symptoms: Volatility, Crises and Growth," Journal of Monetary Economics, 50, 49-123.

Aigner, Dennis J., Cheng Hsiao, Arie Kapetyn, and Tom Wansbreek (2004) "Latent Variable Models in Econometrics" in Handbook of Econometrics II (Z. Griliches and M.D. Intriligator, eds) Elsevier Science, Amsterdam, 1321-1393.

Barth, James, Gerard Caprio, and Ross Levine, (2005), Rethinking Bank Regulation: Till Angels Govern, Cambridge University Press.

Basel Committee on Banking Supervision, (2009), "Proposed Enhancements to the Basel II Framework," Consultative document, Bank for International Settlements, January.

Berg, Andrew, Eduardo Borensztein, and Catherine Patillo, (2004), “Assessing Early Warning Systems: How Have They Worked in Practice?” IMF Working Paper no. WP/04/52, March.

Berg, Andrew, and Catherine Patillo, (1999), "Are Currency Crises Predictable? A Test," International Monetary Fund Staff Papers, Vol. 46, Issue 2 (June), pp. 107-38.

Bernanke, Ben S., (2009a), "Four Questions about the Financial Crisis," speech at Morehouse College, Atlanta, Georgia, April 14.

Bernanke, Ben S., (2009b), "Lessons of the Financial Crisis for Banking Supervision," speech at the Federal Reserve Bank of Chicago Conference on Bank Structure and Competition, Chicago, Illinois, May 7.

Boone, Peter, Simon Johnson, and James Kwak, (2009), "Baseline Scenario, April 7, 2009," http://baselinescenario.com/2009/04/07/baseline-scenario-april-7-2009/

Breusch, Trevor (2005) "Estimating the Underground Economy Using MIMIC Models" ANU working paper.

Brunnermeier, Markus K., (2009), “Deciphering the Liquidity and Credit Crunch 2007,” Journal of Economic Perspectives, 23(1), Winter, 77-100.

Buiter, Willem, (2007), "Lessons from the 2007 Financial Crisis," Background Paper Submitted to the UK Treasury Select Committee, December 11, 2007.

Buiter, Willem, (2009), "Fiscal Expansions in Submerging Markets; the Case of the USA and the UK," ft.com/maverecon, February 5, http://blogs.ft.com/maverecon/2009/02/fiscal-expansionsin-submerging-markets-the-case-of-the-usa-and-the-uk/. 
Calvo, Guillermo and Ruby Look-Kung, "Rapid and Large Liquidity funding for Emerging Markets," in Felton, Andrew and Carmen M. Reinhart, eds., The First Global Crisis of the $21^{\text {st }}$ Century, Part II: June-December 2008 VoxEU.org, 37-41

Cecchetti, Stephen G., (2009), "Crisis and Responses: The Federal Reserve in the Early Stages of the Financial Crisis," Journal of Economic Perspectives, 23(1), Winter, 51-76.

Coval, Joshua, Jacob Jurek, and Erik Stafford, (2009), “The Economics of Structured Finance," Journal of Economic Perspectives, 23(1), Winter, 3-25.

Danielsson, Jon, (2008), "The First Casualty of the Crisis: Iceland," in Andrew Felton and Carmen M. Reinhart, eds. The First Global Financial Crisis of the $21^{\text {st }}$ Century, Part II, JuneDecember 2008, voxeu.org, 9-13.

De Gregorio, José, (2009), “Chile and the Global Recession of 2009," speech at the seminar Los temas del 2009, organized by the Instituto de Politicas Públicas Expansiva - UDP and Libertad y Desarollo, Santiago, Chile, March 20.

De Long, J. Bradford, (2009), "The Financial Crisis of 2007-2009: Understanding its Causes, Consequences - and its Possible Cures," MTI-CSC Economics Speaker Series Lecture, Singapore, January 5, http://www.scribd.com/doc/9719227/null.

De Michelis, Andrea, (2009) "Overcoming the Financial Crisis in the United States," OECD Economics Department Working Paper no. 669, February.

Demirguc-Kunt, Asli and Luis Serven, (2009), "Are the Sacred Cows Dead?: Implications of the Financial Crisis for Macro and Financial Policies," World Bank Policy Research Working Paper no. 4807, January. [DKL]

Doms, Mark, Fred Furlong and John Krainer, (2007), "Subprime Mortgage Delinquency Rates," Federal Reserve Bank of San Francisco Working Paper 2007-33, November.

Egert, B and D Mihaljek (2007) "Determinants of House Prices in Central and Eastern Europe”, BIS Working Paper, no 236.

Ehrmann, Michael, Marcel Fratzscher and Arnaud Mehl, (2009), "What Has Made the Current Financial Crisis Truly Global?," mimeo, European Central Bank.

Eichengreen, Barry, Andrew K. Rose and Charles Wyplosz (1996) "Exchange Market Mayhem: The Antecedents and Aftermath of Speculative Attacks" Economic Policy 10(21), 251-312.

Foroohar, Rana (2008), “Keeping Economics Real,” Newsweek, October 27.

Feldstein, Martin, (2008), “The Problem is Still Falling House Prices: The Bailout Bill Doesn't Get at the Root of the Credit Crunch," Wall Street Journal, October 4. 
Feldstein, Martin, (2009), “The Economic Stimulus and Sustained Economic Growth,” Full Statement for the House Democratic Steering and Policy Committee, January 7.

Frankel, Jeffrey, (2008), “Origins of the Economic Crisis - In One Chart!,” Jeff Frankel's Weblog: Views on the Economy and the World, December 5, http://content.ksg.harvard.edu/blog/jeff_frankels_weblog/category/financial-crisis/.

Fratzscher, Marcel, (2009), "What Explains Global Exchange Rate Movements During the Financial Crisis?, European Central Bank Working Paper, April 8.

Gertler, Paul J. (1988) “A Latent Variable Model of Quality Determination” Journal of Business and Economic Statistics 6, 97-107.

Gieve, Sir John, "Seven Lessons from the Last Three Years," (2009), London School of Economics. London, United Kingdom, February.

Glindro, Eloisa T., Tientip Subhanji, Jessica Szato, and Haibin Zhu, (2008), "Determinants of House Prices in Nine Asia-Pacific Economies," Bureau of International Settlements Working Paper no. 263.

Goldberger, Arthur S. (1972) "Structural Equation Methods in the Social Sciences" Econometrica, 40, 979-1001.

Hall, Robert E., and Susan E. Woodward, (2009), "The Financial Crisis and the Recession: What is Happening and What the Government Should Do," Financial Crisis and Recession, January 1, http://woodwardhall.wordpress.com/.

Kaminsky, Graciela L., Saúl Lizondo, and Carmen M. Reinhart, (1998), "Leading Indicators of Currency Crises," International Monetary Fund Staff Papers, 45(1), 1-48.

Lane Philip, (2008), "Iceland: The Future is in the EU," in Andrew Felton and Carmen M. Reinhart, eds. The First Global Financial Crisis of the $21^{\text {st }}$ Century, Part II, June-December 2008, voxeu.org, 15-17.

Mayer, Christopher, Karen Pence, and Shane M. Sherlund, (2009), "The Rise in Mortgage Defaults," Journal of Economic Perspectives, 23(1), Winter, 27-50.

Mian, Atif, and Amir Sufi, (2008), “The Consequences of Mortgage Credit Expansion: Evidence from the 2007 Mortgage Default Crisis,” NBER Working Paper no. 13936, April.

Mishkin, Frederic S., (2008), "Global Financial Turmoil and the World Economy," Caesarea Forum of the Israel Democracy Institute, Eilat, Israel, July 2. 
Mohan, Dr. Rakesh, (2009), “Global financial Crisis - Causes, Impact, Policy Responses and Lessons," speech at the $7^{\text {th }}$ Annual India Business Forum conference, London Business School, London, United Kingdom, April 23.

Obstfeld, Maurice, Jay C. Shambaugh, and Alan M. Taylor, (2009), "Financial Instability, Reserves, and Central Bank Swap Lines in the Panic of 2008," NBER Working Paper no. 14826, March.

Rabe-Hesketh, Sophia, Anders Skrondal, and Andrew Pickles (2004a) "Generalized Multilevel Structural Equation Modeling” Psychometrika 69 (2), 167-190.

Rabe-Hesketh, Sophia, Anders Skrondal, and Andrew Pickles (2004b) “GLLAMM Manual” UC Berkeley Biostatistics Working Paper 160.

Reinhart, Carmen M. And Vincent Reinhart, (2009), "From Capital Flow Bonanza to Financial Crash," in Felton, Andrew and Carmen M. Reinhart, eds., The First Global Crisis of the $21^{\text {st }}$ Century, Part II: June-December 2008 VoxEU.org, 31-37.

Reinhart, Carmen M. And Kenneth S. Rogoff, (2008), "Is the 2007 US Sub-Prime Crisis So Different? An International Historical Comparison, American Economic Review: Papers and Proceedings, 98:2, 339-344.

Shirakawa, Masaaki, (2009), "Way Out of Economic and Financial Crisis - Lessons and Policy Actions," Japan Society, New York, April 23.

Spence, Michael, (2008), "Balance Sheets and Income Statements: Breaking the Downward Spiral," ft.com/economists forum, November 24, http://blogs.ft.com/economistsforum/2008/11/balance-sheets-and-income-statements-breakingthe-downward-spiral/

Teslik, Lee Hudson, (2008), "Interview, Martin Wolf, The Deep Roots of the Financial Crisis," Council on Foreign Relations, http://www.cfr.org/publication/17553/.

Trichet, Jean-Claude, (2009a), "What Lessons Can be Learned from the Economic and Financial Crisis?," speech at the 5e Recontres de l'Entreprise Européenne, Paris, France, March 17.

Trichet, Jean Claude, (2009b), "The Global Dimension of the Crisis," speech at the Foreign Correspondents' Club of Japan, Tokyo, Japan, April 18.

White, Lawrence H., (2008), "How Did We Get Into This Financial Mess?,” CATO Institute Briefing Paper no. 110, November 18. 


\section{Appendix Table A1: List of Countries and Territories}

\begin{tabular}{|l|l|l|l|}
\hline Albania & Dominican Republic & Kyrgyzstan & Romania \\
\hline Algeria & Ecuador & Latvia & Russia \\
\hline Antigua & Egypt & Lebanon & Saudi Arabia \\
\hline Argentina & El Salvador & Libya & Seychelles \\
\hline Armenia & Equatorial Guinea & Lithuania & Singapore \\
\hline Australia & Estonia & Luxembourg & Slovak Republic \\
\hline Austria & Finland & Macao & Slovenia \\
\hline Bahamas & France & Macedonia & South Africa \\
\hline Bahrain & Gabon & Malaysia & Spain \\
\hline Barbados & Georgia & Malta & Sri Lanka \\
\hline Belarus & Germany & Mauritius & St. Kitts \& Nevis \\
\hline Belgium & Greece & Mexico & Swaziland \\
\hline Bermuda & Guyana & Morocco & Sweden \\
\hline Botswana & Haiti & Namibia & Switzerland \\
\hline Brazil & Hong Kong & Netherlands & Taiwan \\
\hline Brunei & Hungary & Netherlands Antilles & Thailand \\
\hline Bulgaria & Iceland & New Zealand & Trinidad \&Tobago \\
\hline Canada & Indonesia & Norway & Tunisia \\
\hline Chile & Iran & Oman & Turkey \\
\hline China & Ireland & Panama & Turkmenistan \\
\hline Colombia & Israel & Papua New Guinea & Ukraine \\
\hline Costa Rica & Italy & Paraguay & United Arab Emirates \\
\hline Croatia & Jamaica & Peru & United Kingdom \\
\hline Cuba & Japan & Poland & United States \\
\hline Cyprus & Kazakhstan & Portugal & Uruguay \\
\hline Czech Republic & Korea, Republic of & Puerto Rico & Venezuela \\
\hline Denmark & Kuwait & Qatar & \\
\hline
\end{tabular}




\section{Appendix Table A2: Key Data Sources}

Many of our data series were extracted in early 2009 from the World Bank's World Development Indicators. ${ }^{37}$ Other key data sets are listed below. The entire (STATA 10.0) data set is available at http://faculty.haas.berkeley.edu/arose/MIMICData.zip.

Economist Intelligence Unit, Country Reports

- 2008 growth estimate as of 3/2009

National Sources

- Percentage change in 2008 broad stock market index

Euromoney and Institutional Investor magazines

- Country credit ratings

International Monetary Fund, International Financial Statistics

- Percentage change in2008 SDR exchange rate; bank claims/deposits; M2/total (non-gold) reserves; M2/Central Bank Foreign assets

Heritage Foundation, Economic Freedom of the World 2008 Dataset (available at http://www.freetheworld.com/2008/2008Dataset.xls)

- Private sector credit access ; bank ownership ; foreign bank competition; interest rate controls/negative interest rate; credit market regulation; credit/labor/business regulation; economic freedom; government size; legal security of property rights; access to sound money

Barth, Caprio and Levine data set on bank regulation and supervision (available at http://econ.worldbank.org/WBSITE/EXTERNAL/EXTDEC/EXTRESEARCH/0,,contentMDK:20345037 pagePK: 64214825 piPK:64214943 theSitePK:469382,00.html)

- Overall capital stringency; ability to take prompt corrective action; capital regulatory index; official supervisory power; restructuring power; declaring insolvency power;

Lane and Milesi-Ferretti "External Wealth of Nations Mark II" (available at http://www.imf.org/external/pubs/cat/longres.cfm?sk=18942.0)

- Net External Position, percentage GDP 2004

Rose-Spiegel Data set from “Offshore Financial Centers” Economic Journal 2007

- English language dummy; common law; log latitude; currency union; control of corruption; regulatory quality; rule of law

Freedom House (available at http://www.freedomhouse.org/uploads/fiw/FIWAllScores.xls)

- Political rights; civil liberties

Polity IV Data Set (available at http://www.systemicpeace.org/polity/polity4.htm)

- Polity; constraints on executive

World Bank, Global Development Finance

- Debt/GNP; Debt Service/Export; Short/Total Debt

BIS Cross-Country Database and Glindro, et al data set from "Determinants of House Prices in Nine Asia-Pacific Economies," BIS Working Paper no. 263, 2008.

- Real Estate Price Appreciation 
Appendix Table A3: Correlations between Crisis Indicators

\begin{tabular}{|c|c|c|c|c|}
\hline \% Changes, 2008: & Stock Market & Real GDP & Price of SDR & II Rating \\
\hline Stock Market & 1.00 & & & \\
\hline Real GDP & .18 & 1.00 & & \\
\hline Price of SDR & -.13 & -.31 & 1.00 & \\
\hline II Rating & .42 & .40 & -.53 & 1.00 \\
\hline
\end{tabular}

85 Observations 


\section{Endnotes}

${ }^{1}$ Point 15, p3 of Final Communiqué G-20 Summit April 2, 2009, available at http://www.g20.org/Documents/final-communique.pdf. See also Declaration on Strengthening the Financial System (http://www.g20.org/Documents/Fin_Deps_Fin_Reg_Annex_020409_-_1615_final.pdf)

${ }^{2} \mathrm{http} / / / \mathrm{www} . i m f .0 r g / \mathrm{external} / \mathrm{np} / \mathrm{sec} / \mathrm{pr} / 2008 / \mathrm{pr} 08278 . \mathrm{htm}$

${ }^{3}$ Early efforts at early warning systems include Kaminsky, Lizondo and Reinhart (1998) and Berg and Patillo (1999).

${ }^{4}$ For instance, Berg, et al (2004).

${ }^{5}$ We also find a geographic dummy that identifies countries from Eastern Europe and Central Asia to robustly be correlated with the incidence of crises. However, we interpret the strong performance of this geographic variable in the presence of other variables representing the various hypotheses put forward in the literature as primarily a demonstration of the poor performance of these hypotheses empirically.

${ }^{6}$ The specification in Ehrmann, et al (2009) exploits the fact that exposure to American assets is ex post associated with problems. The origins (common or otherwise) of the next crisis (global or not) are currently unknown.

${ }^{7}$ A number of analysts (e.g. Buiter and Sibert, 2008) predicted prior to the collapse of its economy that Iceland faced a choice between adopting the euro or moving its large financial center offshore. Some have argued (e.g. Danielsson, 2008) that Iceland's problems were not due to size alone, but also to its inflation-targeting monetary policy, which kept interest rates high during the boom years and encouraged excessive capital inflows and exchange rate appreciation. Subsequent to its collapse, the call for Iceland to adopt the euro became more prominent, e.g. Lane (2008).

${ }^{8}$ Concerns about the impact of these flows on emerging economies led to "sudden stops" in credit, raising balance of payments concerns that had commonly been thought to be a "...thing of the past" (Trichet, 2009b).

9 See, e.g. Foroohar (2008).

${ }^{10}$ See Table 5 for years used in causal measures.

11 The "Big Five" postwar crises include Spain (1977), Norway (1987), Finland (1991), Sweden (1991), and Japan (1992).

${ }^{12}$ One would also like to have measures of international integration on both the real (trade) and financial sides; we plan to pursue this in future analysis.

${ }^{13}$ Kadee Russ has suggested using the steepness of the yield curve; we are grateful to her for this suggestion and plan to pursue it in future research.

${ }^{14}$ Expressed alternatively, our cross-sectional approach can be viewed as a test of the no "pure contagion or common shock" hypothesis, i.e. No exposure to global shocks whose impact is invariant to national fundamentals. Ehrmann et al (2009) investigate contagion with some success. They also note (on p2): "If investors focus on reducing macroeconomic risks, or country risk, which may be closely related to macroeconomic policies and fundamentals, this would imply that countries with weaker fundamentals have been more severely affected via capital outflows and equity price declines during the crisis."

${ }^{15}$ We refer below to all these entities as "countries" simply for the sake of convenience.

${ }^{16}$ We use 2003 since we used the Penn World Table Mark 6.2 which ends in 2004 and has a number of missing values for that year. Our measure of income in the PWT6.2 is "rgdpl".

17 The list of 81 countries with PWT6.2 data that are omitted from our sample is: Afghanistan, Angola, Azerbaijan, Bangladesh, Belize, Benin, Bhutan, Bolivia, Bosnia and Herzegovina, Burkina Faso, Burundi, Cambodia, Cameroon, Cape Verde, Central African Republic, Chad, Comoros, Congo, Dem. Rep., Congo, Republic of, Cote d'Ivoire, Djibouti, Dominica, Eritrea, Ethiopia, Fiji, Gambia, The, Ghana, Grenada, Guatemala, Guinea, GuineaBissau, Honduras, India, Iraq, Jordan, Kenya, Kiribati, Korea, Dem. Rep., Laos, Lesotho, Liberia, Madagascar, Malawi, Maldives, Mali, Mauritania, Micronesia, Fed. Sts., Moldova, Mongolia, Mozambique, Nepal, Nicaragua, Niger, Nigeria, Pakistan, Palau, Philippines, Rwanda, Samoa, Sao Tome and Principe, Senegal, Serbia and Montenegro, Sierra Leone, Solomon Islands, Somalia, St. Lucia, St. Vincent \& Grenadines, Sudan, Suriname, Syria, Tajikistan, Tanzania, Togo, Tonga, Uganda, Uzbekistan, Vanuatu, Vietnam, Yemen, Zambia, and Zimbabwe. ${ }^{18}$ Using 2008 seems like a reasonable choice to us. Though some of the real effects of the crisis began before 2008 (the NBER Dating Committee uses December 2007 as the cyclic peak for the United States), the dramatic downturns took place in the latter part of 2008. Similarly while some financial distress began in the late summer of 2007 (or somewhat earlier), restricting our analysis to the larger events of 2008 seems reasonable, given that our focus is cross-country in nature. But we restrict our attention to crisis causes from 2006 and earlier to avoid any overlap between causes and consequences of the crisis. 
19 The EIU forecast of 2009 growth is highly positively correlated across countries with their 2008 estimates. Since countries have differing underlying growth rates, one would prefer to account for this by e.g., using the size of the output gap, but we know of no source for such data. Below, we check for differences in growth rates crudely by replacing 2008 growth rates with the difference between 2008 and 2006 growth rates; this makes no difference to our results in practice.

${ }^{20}$ Institutional Investor states that their ratings “... are based on information provided by senior economists and sovereign-risk analysts at leading global banks and money management and securities firm"; further details are available at: http://www.iimagazinerankings.com/rankingsRankCCMaGlobal09/methodology.asp.

${ }^{21}$ We note in passing that we gathered data on changes in sovereign ratings (short- and long-term on both domestic and foreign debt, as relevant) from Standard and Poor's, Moody's and Fitch. However, these ratings change little over the course of 2008, so we were unable to integrate sovereign rating changes sensibly into our measure of crisis incidence.

${ }^{22}$ In this exercise, the eigenvalues for this exercise fall off quickly in size (while the first eigenvalue is 1.33 , the second is only.11 and the final two are negative).

${ }^{23}$ Size is of special interest, since some believe that a key message of the crisis is that some countries are too small to "go it alone." However, the fact that the crisis first hit primarily rich countries is also the subject of considerable discussion.

${ }^{24}$ We use 2006 WDI data on real GDP per capita, measured in PPP-adjusted terms.

${ }^{25}$ Our normalization implies that the latent variable estimate should be interpreted as decreasing in crisis severity.

${ }^{26}$ We only examine a single latent variable, which we interpret as crisis severity. Consistent with our factor analysis results, we have looked without success for a second latent variable, which might represent a different dimension of the crisis; this might be an interesting topic for future work.

${ }^{27}$ Much of the previous literature on the determinants of financial crises (e.g. Kaminsky, Lizondo and Reinhart, 1998) and Berg and Patillo, 1999) follow Eichengreen et al (1996) and use discrete characterizations of economies as being in or out of crisis, either in an ad hoc way or based on some objective criteria; this variable as then treated as observed without error. In actuality, the severity of a crisis is like to be a continuous variable, and one that is only observed with error. The MIMIC framework accounts for both measurement error and continuity.

${ }^{28}$ Occasionally we use a different iterative technique to achieve convergence.

${ }^{29}$ We follow Breusch (2005) in choosing to load first on the stock market because it delivers the best fit in a bivariate regression than any of our other three crisis indicators.

${ }^{30}$ As other causes are added to the MIMIC model, the effect of size remains economically and statistically small essentially throughout, while income continues to have a mostly negative and significant effect on crisis incidence. 31 The number of observations available varies by cause because of data availability. When we include real estate appreciation, the number of observations in our sample decreases to 36 . We also note in passing that an additional source of data is available that contains housing price appreciation data from 2002-2006 for eight Eastern European countries (Egert and Mihaljek, 2007). While the timing does not exactly match our housing data (which runs from 2003-2006), we have added these observations to the sample, thereby increasing our sample size to 44. However, real estate price appreciation continues to enter as statistically insignificant.

32 We add our causes measured on a country by country format, not as differentials with respect to (e.g., ) the United States. It is conceivable that this may partially explain the poor performance of macroeconomic fundamentals in our analysis.

${ }^{33}$ Since real estate prices are available for a smaller set of countries, the inclusion of our real estate variable does cut down our sample and it may be the sample truncation that is precluding statistical significance for real estate appreciation.

${ }^{34}$ The regression yields a t-statistic of 0.8 .

${ }^{35}$ We define big commodity exporters as: a) all past or present OPEC countries; b) Norway, Russia, Mexico and Kazakhstan, all big non-OPEC oil exporters; c) the Chen-Rogoff C-3 countries: Australia, Canada, and New Zealand; d) any country listed in the CIA World Factbook (https://www.cia.gov/library/publications/the-worldfactbook/fields/2049.html) as having $>50 \%$ exports from commodities; and e) any country listed in Cashin et al (http://www.imf.org/external/pubs/ft/fandd/2003/03/cash.htm).

${ }^{36}$ When we substitute the 2009 growth forecasts from the EIU (as reported in early March 2009) for the 2008 estimates, our results change in economically and statistically trivial ways. The same is true if we replace 2008 growth by the difference between 2008 and 2006 growth rates.

37 This includes series on: population; real GDP per capita; non-performing loans/loans; bank capital/assets; current account/GDP; central government debt/GDP; CPI Inflation; Real GDP growth; total debt service/GDP; M2/GDP; 
M3/GDP; bank liquid reserves/assets; domestic bank credit/GDP; domestic credit to private sector/GDP; external debt/GNI; real effective exchange rate; total reserves/imports; gross financing via international capital markets/GDP; government budget surplus/deficit/GDP; short-term debt/reserves; reserves/debt; stock market capitalization/GDP; S\&P/EMDB index change; and stocks traded/GDP. 